\title{
The MEDITS maturity scales as a useful tool for investigating the reproductive traits of key species in the Mediterranean Sea
}

\author{
Maria Cristina Follesa ${ }^{1}$, Blondine Agus ${ }^{1}$, Andrea Bellodi ${ }^{1}$, Rita Cannas ${ }^{1}$, \\ Francesca Capezzuto ${ }^{2}$, Loredana Casciaro ${ }^{3}$, Alessandro Cau ${ }^{1}$, Danila Cuccu ${ }^{1}$, \\ Marilena Donnaloia ${ }^{3}$, Ulla Fernandez-Arcaya ${ }^{4}$, Vita Gancitano ${ }^{5}$, Palma Gaudio ${ }^{3}$, \\ Martina Francesca Marongiu ${ }^{1}$, Antonello Mulas ${ }^{1}$, Paola Pesci ${ }^{1}$, Cristina Porcu ${ }^{1}$, \\ Ilaria Rossetti ${ }^{7}$, Letizia Sion ${ }^{2}$, Maria Vallisneri ${ }^{6}$, Pierluigi Carbonara ${ }^{3}$ \\ ${ }^{1}$ Department of Life and Environmental Sciences, University of Cagliari, Via T. Fiorelli 1, Cagliari. Italy. \\ (CF) (Corresponding author) E-mail: follesac@ unica.it. ORCID iD: http://orcid.org/0000-0001-8320-9974 \\ (BA) E-mail: blondine.agus@unica.it. ORCID iD: http://orcid.org/0000-0002-1180-2362 \\ (AB) E-mail: abellodi@ unica.it. ORCID iD: http://orcid.org/0000-0002-9017-1692 \\ (RC) E-mail: rcannas@unica.it. ORCID iD: http://orcid.org/0000-0001-6627-4053 \\ (AC) E-mail: alessandrocau@unica.it. ORCID iD: http://orcid.org/0000-0003-4082-7531 \\ (DC) E-mail: cuccu@ unica.it. ORCID iD: http://orcid.org/0000-0001-5638-8209 \\ (MFM) E-mail: mfmarongiu @ unica.it. ORCID iD: http://orcid.org/0000-0002-0582-8865 \\ (AM) E-mail: amulas@ unica.it. ORCID iD: http://orcid.org/0000-0003-1635-691X \\ (PP) E-mail: ppesci@unica.it. ORCID iD: http://orcid.org/0000-0002-9066-8076 \\ (CP) E- mail: cporcu@ unica.it. ORCID iD: http://orcid.org/0000-0003-2649-6502 \\ 2 Department of Biology, University of Bari Aldo Moro, Via Orabona 4, 70125 Bari, Italy. \\ (FC) E-mail: francesca.capezzuto@uniba.it. ORCID iD: http://orcid.org/0000-0002-1498-0228 \\ (LS) E-mail: letizia.sion@uniba.it. ORCID iD: http://orcid.org/0000-0002-0308-1841 \\ ${ }^{3}$ COISPA Tecnologia \& Ricerca, via dei Trulli, 18-20, Bari, Italy. \\ (LC) E-mail: casciaro@ coispa.it. ORCID iD: http://orcid.org/ORCID.ID: 0000-0003-4876-9874 \\ (MD) E-mail: donnaloia@ coispa.eu. ORCID iD: http://orcid.org/0000-0001-6707-0503 \\ (PG) E-mail: gaudio@ coispa.it. ORCID iD: http://orcid.org/0000-0002-8501-1168 \\ (PC) E-mail: carbonara@ @oispa.it. ORCID iD: http://orcid.org/0000-0002-2529-2535 \\ ${ }^{4}$ Instituto Español de Oceanografia, Centre Oceanogràfic de les Balears, Moll de Ponent s/n, 07015 Palma de Mallorca, \\ Illes Baleares, Spain. \\ (UFA) E-mail: fernandez.arcaya@gmail.com. ORCID iD: http://orcid.org/0000-0002-5588-3520 \\ ${ }^{5}$ National Research Council, Institute for Coastal Marine Environment, Via Vaccara, 61, 91026 Mazara del Vallo, Trapani \\ Italy. \\ (VG) vita.gancitano@cnr.it. ORCID iD: http://orcid.org/0000-0001-9623-6621 \\ ${ }^{6}$ Department of Biological, Geological and Environmental Sciences (BIGEA), University of Bologna, Italy. \\ (MV) E-mail: maria.vallisneri@unibo.it. ORCID iD: http://orcid.org/0000-0002-6323-4328 \\ ${ }^{7}$ APLYSIA Soc. Coop. r.l., Via Menichetti 35, Livorno, Italy. \\ (IR) E-mail: ilaria.rossetti@aplysia.it. ORCID iD: http://orcid.org/0000-0003-3260-8769
}

\begin{abstract}
Summary: Maturity is one of the most important biological parameters used in stock assessment programmes. Indeed, the macroscopic stage of gonadal development is an essential feature in estimating the maturity ogive and spawning stock biomass. It is also useful for determining the spawning season of a species and for monitoring long-term changes in the spawning cycle as well as for many other research needs related to the biology of fish. Despite the efforts made during the last few decades to standardize maturity stage data among all the researchers, marine biologists continue without a manageable and unique maturity scale to describe the reproductive development of fish gonads. For these reasons, the objectives of this article are 1) to investigate the biological parameters of five selected key species (Mullus barbatus, Galeus melastomus, Etmopterus spinax, Aristeus antennatus, Loligo vulgaris) with different reproductive strategies following the macroscopic maturity scales based on the same univocal criteria adopted in the MEDITS programme and described in this work; and 2) to compare them among some Mediterranean geographical sub-areas (GSAs) involved in the programme. Neither spawning periods nor size at first maturity $\left(\mathrm{SFM}_{50}\right)$ for the studied species showed particular differences in the investigated GSAs.
\end{abstract}

Keywords: MEDITS maturity scales; reproduction; fish; cephalopods; crustaceans; Mediterranean Sea.

Uso de las escalas de madurez de MEDITS como una herramienta útil para investigar las características reproductivas de especies clave en el mar Mediterráneo 


\begin{abstract}
Resumen: La madurez es uno de los parámetros biológicos más relevantes utilizados en los programas de evaluación de stock. De hecho, la etapa macroscópica del desarrollo gonadal es una característica esencial en la estimación de la madurez de la biomasa de la ojiva y del desove. También es útil para determinar la temporada de desove de una especie y para monitorear los cambios a largo plazo en el ciclo de desove, así como para muchas otras necesidades de investigación relacionadas con la biología de los peces. A pesar de los esfuerzos realizados durante las últimas décadas para estandarizar los datos de las etapas de madurez entre todos los investigadores, los biólogos marinos continúan sin una escala de madurez única y manejable para describir el desarrollo reproductivo de las gónadas de peces. Por estas razones, el objetivo de este artículo es 1) investigar los parámetros biológicos de 5 especies clave seleccionadas (Mullus barbatus, Galeus melastomus, Etmopterus spinax, Aristeus antennatus, Loligo vulgaris) con diferentes estrategias reproductivas siguiendo las escalas de madurez macroscópica basadas en criterios iguales y unívocos adoptados en el programa MEDITS y descritos en este trabajo y 2) para compararlos entre algunas sub-áreas geográficas del Mediterráneo (GSAs) involucradas en el programa. Tanto los períodos de desove como el tamaño en la primera madurez $\left(\mathrm{SFM}_{50}\right)$ para las especies estudiadas no han mostrado diferencias particulares en las GSA investigadas.
\end{abstract}

Palabras claves: escalas de madurez de MEDITS; reproducción; pez; cefalópodos; crustáceos; mar Mediterráneo.

Citation/Cómo citar este artículo: Follesa M.C., Agus B., Bellodi A., Cannas R., Capezzuto F., Casciaro L., Cau A., Cuccu D., Donnaloia M., Fernandez-Arcaya U., Gancitano V., Gaudio P., Marongiu M.F., Mulas A., Pesci P., Porcu C., Rossetti I., Sion L., Vallisneri M., Carbonara P. 2019. The MEDITS maturity scales as a useful tool for investigating the reproductive traits of key species in the Mediterranean Sea. Sci. Mar. 83S1: 235-256. https://doi.org/10.3989/scimar.04965.15A

Editor: G. Tserpes.

Received: July 25, 2018. Accepted: April 19, 2019. Published: October 1, 2019.

Copyright: (C) 2019 CSIC. This is an open-access article distributed under the terms of the Creative Commons Attribution 4.0 International (CC BY 4.0) License.

\section{INTRODUCTION}

An accurate assessment of population parameters related to fish reproduction is an essential component for an effective fisheries management (Brown-Peterson et al. 2011). As reported by Kjesbu (2009) and Lowerre-Barbieri (2009), reproductive success and population reproductive potential are strictly related to fisheries.

Indeed, sustainable management and exploitation of fish resources are closely related to the stock reproductive potential concept (Trippel 1999) which, in stock assessment, appears to be an essential concept for several commercially important demersal or semidemersal species (Murua and Saborido-Rey 2003, Murua et al. 2003). The macroscopic stage of gonadal development is an essential feature in estimating the maturity ogive and spawning stock biomass (SSB). It is also useful for determining the spawning season of a species and for monitoring long-term changes in the spawning cycle, as well as for many other research needs related to the biology of fish (Follesa and Carbonara 2019).

The Data Collection Framework programme (DCF, EU Reg. 1543/2000, 1639/2001, 1581/2004 and $199 / 2008)$ covers a long-term monitoring of key species including extensive samplings of maturity stages of stocks within European Union waters. However, the surveys have specific technical limitations that need to be considered prior to an assessment. For example, for some target species, survey data do not always cover the spawning season of populations, the difference in coding schemes used (varying from a 4grade scale to a 10grade scale), and the interpretation of particular stages (in particular immature versus postspawning or skippedspawning) gives rise to misinterpretations that could be reflect on the assessment of the maturity ogive and the SSB. Consequently, although the current DCF establishes a high level of accuracy for determining the maturity stages, the aimed precision has not yet been achieved; thus, several stock assessments based on time-invariant maturity ogives are incomplete in covering the spatial distribution of the stocks.

In the last decade, a series of workshops organized by several international commissions for fisheries studies in the International Council for the Exploration of the Sea (ICES), North Pacific Marine Science Organization (PICES) and General Fisheries Commission for the Mediterranean (GFCM), have been conducted to address the maturity staging of species with the objective of developing common maturity scales within partners, decreasing discrepancies between laboratories and validating maturity staging through microscopic evaluation (ICES 2007, 2008, 2009a). However, despite the efforts made during the last decade to standardize methodologies among all participating countries (especially in ICES and GFCM), the partners continue without a manageable and consistently terminology to describe the reproductive development, especially for fish gonads (Brown-Peterson et al. 2011). The lack of standardized scales makes it difficult to compare reproductive timing over space, time, or among populations (ICES $2008,2015)$. In addition, there is a need to improve our understanding of how, when and where fish spawn in order to determine the effects of spatio-temporal variables on recruitment success and the effects of explicit management measures on spawning populations (i.e. Marine Protected Areas; Huret et al. 2007, Botsford et al. 2009, Pecquerie et al. 2009).

Most commercially targeted teleost species are iteroparous (i.e. have a multiple breading season) and may have different spawning patterns: batch spawners (which release multiple batches of eggs per breeding season) (Murua and Saborido-Rey 2003) or total spawners (which release one batch of eggs per breeding season) (Brown-Peterson et al. 2011). Specific differences in the reproduction modality (Saborido-Rey 


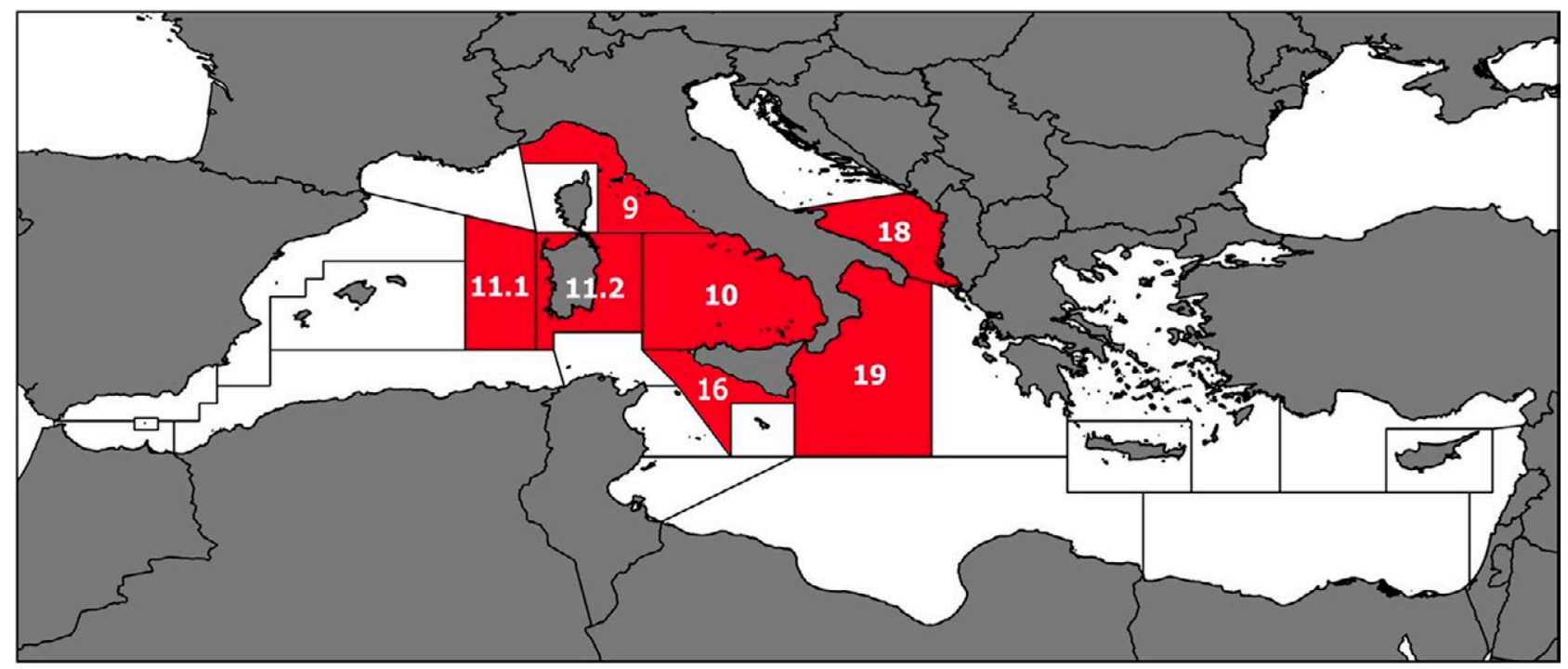

Fig. 1. - Map of the study areas where the samples were collected. GSA 9, Ligurian and north Tyrrhenian Sea; GSA 10, south and central Tyrrhenian Sea; GSA 11, Sardinian seas; GSA 16, south of Sicily, GSA 18, southern Adriatic Sea, GSA 19, western Ionian Sea.

2016) can be also found in species showing alternate reproductive strategies (i.e. hermaphrodites and livebearing fishes) or in semelparous species (which spawn once and die).

A series of reproductive strategies has been developed during the evolutionary history of Chondrichthyes with a progression from oviparity to viviparity. For oviparous species, the general trend is a reproduction throughout the year with one or two egg-laying peaks. Reproductive periods of viviparous species are generally well circumscribed annual cycles, with the entire population undergoing nearly synchronous mating, gestation and parturition.

In summary, reproductive timing is highly variable in marine organisms, and a comprehensive understanding of variability in reproductive timing over species, population and temporal scales is lacking.

Therefore, the objective of this article is 1) to investigate the biological parameters of five selected key species with different reproductive strategies following the macroscopic maturity scales (Anonymous 2016) based on the same univocal criteria adopted in the Mediterranean International Trawl Survey (MEDITS) programme and 2) to compare them among some Mediterranean geographical sub-areas (GSAs) involved in the programme.

\section{MATERIALS AND METHODS}

Biological samplings were carried out all year round in 2015-2017 both on board commercial vessels during the MEDITS surveys and at landing points, according to the framework lines of the Common Fisheries Policy (Council Regulation EC N¹99/2008 and Commission Regulation EC N665/2008). Therefore, the commercial samplings, from both fish marker and observers on board, were performed throughout the year in order to collect biological data and store gonads of the species whose spawning period does not coincide with the MEDITS survey season (mainly from May to July).
As far as possible, data on maturity stages were collected using fresh gonad samples in order to perform appropriate histological analysis. Images were collected by researchers from different GSAs (GSAs $9,10,11,16,17,18,19)$ and involved in national and international scientific research programmes (Fig. 1).

\section{Protocol of the macroscopic material collection}

The macroscopic scales used in the present study are based on the female maturity scales from the MEDITSHandbook Version n. 8 (Anonymous 2016). In particular, one species for each systematic category was chosen:

Mullus barbatus Linnaeus, 1758 (red mullet) for Osteichthyes - iteroparous and batch spawner (Carbonara et al. 2015);

Galeus melastomus Rafinesque, 1810 (blackmouth catshark) for oviparous Elasmobranchii - lecitothrophic with multiple oviparity (Hamlett 2005);

Etmopterus spinax (Linnaeus, 1758) (velvet belly lanternshark) for viviparous Elasmobranchii- lecithotrophic, yolk sac viviparous (Hamlett 2005);

Aristeus antennatus (Risso, 1816) (blue and red shrimp) for Crustacea - iteroparous and total spawner (Carbonell et al. 2006);

Loligo vulgaris Lamarck, 1798 (European squid) for Cephalopoda - semelparous and intermittent terminal spawning (Rocha et al. 2001).

A photo of each gonad was taken according to an established protocol (Follesa and Carbonara 2019). Both the gonad inside the cavity and the unit of measure had to be perfectly visible in order to perceive the ratio between the gonad and cavity dimensions (Follesa and Carbonara 2019). Additionally, the collection of particular secondary maturity structures for Elasmobranchii and Cephalopoda was also included. The microscales proposed in this paper aimed to be as wide-ranging as possible, though the information available was limited to just a few species. Considering the recommenda- 
Table 1. - Summary of sample number and sample size range of mature specimens of key species for each GSA analysed. Size $=$ total length $(\mathrm{cm})$ for fish, cephalo-thoracic length $(\mathrm{mm})$ for crustaceans, dorsal mantle length $(\mathrm{cm})$ for cephalopods.

\begin{tabular}{|c|c|c|c|c|c|}
\hline \multirow{2}{*}{ Species } & \multirow{2}{*}{ GSA } & \multicolumn{2}{|c|}{ Reproductive period } & \multicolumn{2}{|c|}{ Size at first maturity } \\
\hline & & Sample number & Sample size range & Sample number & Sample size range \\
\hline M. barbatus & $\begin{array}{c}9 \\
10 \\
11 \\
16 \\
18 \\
19\end{array}$ & $\begin{array}{c}4860 \\
19770 \\
3735 \\
5882 \\
45275 \\
26503\end{array}$ & $\begin{array}{c}10.0-27.0 \\
9.5-24.5 \\
10.0-25.0 \\
10.0-25.0 \\
10.0-27.5 \\
9.5-27.0\end{array}$ & $\begin{array}{c}4962 \\
1149 \\
2646 \\
7129 \\
3021 \\
29885\end{array}$ & $\begin{array}{c}10.0-26.5 \\
11.0-26.0 \\
10.0-25 \\
9.0-25.0 \\
10.0-26.5 \\
9.5-27.0\end{array}$ \\
\hline G. melastomus & $\begin{array}{c}9 \\
10 \\
11 \\
16 \\
18 \\
19\end{array}$ & $\begin{array}{l}865 \\
615 \\
670 \\
621 \\
426 \\
562\end{array}$ & $\begin{array}{l}32.0-56.0 \\
41.0-54.5 \\
39.5-54.5 \\
31.0-55.0 \\
37.5-57.0 \\
42.0-55.5\end{array}$ & $\begin{array}{c}3704 \\
260 \\
1728 \\
- \\
134 \\
562\end{array}$ & $\begin{array}{c}32.0-56.0 \\
42.5-54.5 \\
38.0-54.5 \\
- \\
37.5-57.0 \\
42.0-55.5\end{array}$ \\
\hline E. spinax & $\begin{array}{c}9 \\
10 \\
11 \\
16 \\
18 \\
19\end{array}$ & $\begin{array}{c}48 \\
43 \\
68 \\
709 \\
29 \\
27\end{array}$ & $\begin{array}{l}28.0-43.0 \\
33.0-44.0 \\
35.0-44.5 \\
24.5-52.5 \\
31.0-39.5 \\
31.5-40.5\end{array}$ & $\begin{array}{c}493 \\
44 \\
135 \\
- \\
29 \\
32\end{array}$ & $\begin{array}{c}28.0-43.0 \\
33.0-44.0 \\
10.5-44.5 \\
- \\
31.0-39.5 \\
31.5-40.5\end{array}$ \\
\hline A. antennatus & $\begin{array}{c}9 \\
10 \\
11 \\
16 \\
19\end{array}$ & $\begin{array}{c}5513 \\
15003 \\
11733 \\
3298 \\
70084\end{array}$ & $\begin{array}{l}19.0-66.0 \\
21.0-67.0 \\
18.0-60.0 \\
21.0-59.0 \\
19.0-65.0\end{array}$ & $\begin{array}{c}582 \\
1135 \\
4715 \\
- \\
73652\end{array}$ & $\begin{array}{c}23.0-66.0 \\
21.0-62.0 \\
18.0-60.0 \\
- \\
19.0-65.0\end{array}$ \\
\hline L. vulgaris & $\begin{array}{c}9 \\
10 \\
11 \\
16 \\
18 \\
19\end{array}$ & $\begin{array}{c}112 \\
18 \\
36 \\
539 \\
100 \\
16\end{array}$ & $\begin{array}{l}10.5-26.0 \\
14.0-25.0 \\
14.5-26.5 \\
10.0-40.0 \\
11.5-23.5 \\
12.0-21.5\end{array}$ & $\begin{array}{c}418 \\
- \\
516 \\
1695 \\
77 \\
12\end{array}$ & $\begin{array}{c}10.5-21.0 \\
- \\
14.5-26.5 \\
10.0-40.0 \\
11.5-23.5 \\
12.0-21.5\end{array}$ \\
\hline
\end{tabular}

tions of the Workshop on Sexual Maturity Staging of Elasmobranchs (WKMSEL2 - ICES 2013), the tables of Elasmobranchii were structured for different reproductive organs by maturity stage: ovaries, oviducal glands and uteri. For Cephalopoda species, the sexual maturity process involves the ovary, the single left oviduct and also glandular structures such as the nidamental, accessory nidamental and oviducal glands.

For each maturity stage, the following sampling biological metrics were reported: Length of specimen; total weight and sampling time. In particular, for fish (Osteichthyes and Elasmobranchii) the total length (TL) with the tail fully extended was recorded to the lowest $0.5 \mathrm{~cm}$. For Crustacea, the cephalo-thoracic length (CL) at the lowest $0.1 \mathrm{~mm}$ was measured, while for Cephalopoda, the dorsal mantle length (ML) to the lowest $0.5 \mathrm{~cm}$ was obtained.

In order to confirm the assigned macroscopic maturity stages, a histological analysis was conducted following the description and terminology of oocyte stages proposed by Brown-Petersen et al. (2011) for Osteichthyes, by Porcu et al. (2014) for Elasmobranchii, by Cuccu et al. (2013) for Cephalopoda and by ICES (2009b) for Crustacea.

\section{Protocol of the microscopic material collection}

The histological protocol used by all involved laboratories for all analysed species followed Mazzi (1977) and Cerri and Sasso-Cerri (2003) for the slide section and the staining respectively, as follows: fixation in $5 \%$ buffered formaldehyde $(0.1 \mathrm{M}, \mathrm{pH}$ 7.4) for a maximum period of $48 \mathrm{~h}$ and storage in ethanol 70\%; dehydration through a progressively higher series of alcohol concentrations (70\%-100\%), embedding in a synthetic resin (GMA, Technovit 7100, BioOptica), cutting at $3.5 \mu \mathrm{m}$ with a rotative microtome (LKB, Historange) and staining with techniques including Gill or Carazzi's haematoxylin and alcoholic eosin or toluidine blue (to analyse the histological structure of ovaries, and oviducal glands), All sections were then observed using a Zeiss Primo Star optical microscope equipped with a Canon EOS 1100D at different magnifications $(40 \times, 100 \times, 400 \times)$, edited with Adobe Photoshop CS6.

\section{Biological parameters}

All reproductive parameters were estimated for 6 GSAs (GSA 9, 10, 11, 16, 18 and 19) considering the years 2015, 2016 and 2017. The sample size for each GSA is showed in Table 1.

The reproductive seasonality of the target species was inferred through an analysis of the seasonal/ monthly evolution of the percentage of maturity stages of females.

Size at first maturity $\left(\mathrm{SFM}_{50}=\right.$ length at which $50 \%$ of the individuals are mature) was estimated by fitting maturity ogives to the proportion of mature individuals in each size class $(1 \mathrm{~cm}$ for Osteichthyes and Elasmobranchii, $0.5 \mathrm{~cm}$ for Cephalopoda and $1 \mathrm{~mm}$ for Crustacea). The mature portion included stages $2 \mathrm{~b}-4 \mathrm{~b}$ for Osteichthyes, stages $3 \mathrm{a}-4 \mathrm{~b}$ for Elasmobranchii, 
stages $2 b-3 b$ for Cephalopoda and stages $2 b-2 e$ for Crustacea. The $\mathrm{SFM}_{50}$ and the maturity range (length range between $\mathrm{SFM}_{75}$ and $\mathrm{SFM}_{25} ; \mathrm{MR}=\mathrm{SFM}_{75}$ $\mathrm{SFM}_{25}$ where $\mathrm{SFM}_{75}$ and $\mathrm{SFM}_{25}$ are the length at which $75 \%$ and $25 \%$ of the individuals are mature respectively) were estimated using the following ogive model: $M(L)=e(a+b L) / 1+e(a+b L)$, where $M(L)$ is the proportion of adult individuals (ICES 2008) and L the length class. Binomial generalized linear models with logistic link were used to model the proportion of adult individuals on length as an independent variable (ICES 2008). MEDITS data were used for Osteichthyes, Elasmobranchii and Crustacea target species, while for Cephalopoda, when available, commercial data were used.

The maturity stage changes in the gonado-somatic index (GSI) of viviparous elasmobranchs were calculated as follows GSI $=(\mathrm{GM} / \mathrm{TW}) \times 100$, where $\mathrm{GM}$ was the gonad mass and TW the total weight.

\section{RESULTS}

Both macroscopic and microscopic stage description for each chosen target species is reported as follows.

\section{Osteichthyes: Mullus barbatus}

The description of the macroscale of red mullet fits well with what is reported in the MEDITS manual for Osteichthyes (Table 2).

The gonads modify colour with the progression of their maturation development, changing from pinkish/ reddish (stages $2 \mathrm{a}$ and $2 \mathrm{~b}$ named respectively virgin developing and recovering) to pinkish orange (stages $2 \mathrm{c}$ and 3 named respectively maturing and maturespawner). Also the dimension switches from being $1 / 3$ - 1/2 of the body cavity in the immature (stage 1 ) and developing (stage 2a) stages to being from $2 / 3$ to full length of the body cavity in the maturing and mature stages (stages $2 \mathrm{c}$ and 3). Post-spawning stages (stages $4 \mathrm{a}$ and $4 \mathrm{~b}$ named respectively spent and resting) are characterized by a reddish progressively shrunken ovary. The eggs are visible to the naked eye in the maturing, mature and spent stages, but they escape freely from the abdomen only in mature condition (Table 2).

The histological criteria used to distinguish the reproductive stages of $M$. barbatus females are presented in Table 3 . The immature stage 1 appears histologically similar to that of other bony fish. This stage can be distinguished by the presence of oogonia and primary growth oocytes (PG), little connective tissue between follicles and a thin ovarian wall. As females move into the developing stage (stage 2a) and maturing stage (stage 2c), they can be histologically distinguished by the initial appearance of cortical alveoli oocytes (CA) and of vitellogenic oocytes (Vtg1 and Vtg2). The appearance of CA oocytes and the physiological initiator for their formation nevertheless provide the definitive marker for entry into the developing stage. Fish enter the developing phase only one time during a reproductive cycle. The mature/spawner stage (stage 3 ) is defined as the fish is being capable of spawning within the current reproductive cycle. Any fish with Vtg3 oocytes is assigned to the mature stage. Fish undergoing early stages of oocyte maturation (OM) (i.e. germinal vesicle migration) are also considered to be in the mature/spawner stage (stage 3). In M. barbatus, as in other batch spawners, the presence of all stages of oocytes (i.e., PG, CA, Vtg 1, Vtg 2, Vtg 3 and OM) is observed (Carbonara et al. 2015), whereas in total spawners Vtg3 or early OM and PG are the only oocytes present. The evidence that batch spawner fish, in stage 3 , have already spawned in a previous event could be detected by the presences of post-ovulatory follicles.

The end of the spawning season is indicated by the capture of numerous females in the spent stage (stage 4a). From the histological point of view this stage is characterized by abundant atresia, POFs, and few (if any) healthy Vtg2 or Vtg3 oocytes. Fish remain at this stage for a relatively short time and then move to the resting stage (stage $4 \mathrm{~b}$ ) distinguished by the presence of a lot of PG, similar to the immature stage, but with a thicker ovarian wall, the presence of more space, interstitial tissue, capillaries around PG oocytes and the presence of atretic oocytes. Fish at this stage are sexually mature but reproductively inactive. Substage $2 \mathrm{~b}$ represents specimens that have finished a reproductive cycle and are preparing to start another one. At this stage the specimens are inactive mature, the gonad has undergone development but it has taken part in the spawning in the current year. The only fish actually spawning and reproducing in the current year are those in (sub)-stages 2b, 2c, 3 and 4 (both substages $4 a$ and $4 b)$.

\section{Oviparous Elasmobranchii: Galeus melastomus}

In the case of Galeus melastomus, in general the description of the macroscale fitted well with what is reported in the MEDITS manual for oviparous Elasmobranchii. Only some specific integrations are reported in bold in Table 4.

As defined in the WKMSEL2 (ICES 2013), the juvenile females can be assigned to an immature stage (stage 1) when a cut is made in the ovary and no follicles are observed inside. Generally, in this stage, a primordium of the oviducal gland, as a thickening of the uterus, can be identified in some skate species but is less distinguishable in sharks.

The maturing stage (stage 2 ) is characterized by the presence of ovarian follicles of small-medium size, but no large ones are present. Large yolked follicles, ready to be ovulated, can be observed only in the mature specimens (stage $3 \mathrm{a}$ - mature), which will be considered as mature "extruding" only when egg capsules are present (stage $3 b$ mature-extruding). Indeed, the characteristics of the ovary in stage $3 \mathrm{a}$ and $3 \mathrm{~b}$ are the same; the only difference can be found in the presence of egg capsules in $3 b$ (Table 4). In extruding females of G. melastomus, a lecithotrophic species with multiple oviparity, more than one egg capsule in each oviduct can be found, unlike in other members of the Scyliorhinidae or Rajidae family characterized by a single oviparity (Fig. 2). 
240 - M.C. Follesa et al.

Table 2. - Description of the macroscopic maturity scale of M. barbatus females (TL, total length; TW, total weight; ST, sampling time).

\begin{tabular}{lll}
\hline Stage & Photos & Gonad description \\
\hline
\end{tabular}

$1-$ Immature $=$ Virgin

$2 \mathrm{~A}-$ Virgin developing

2B - Recovering

\section{C-Maturing}

3 - Mature/Spawner

$4 \mathrm{~A}-$ Spent

4B - Resting

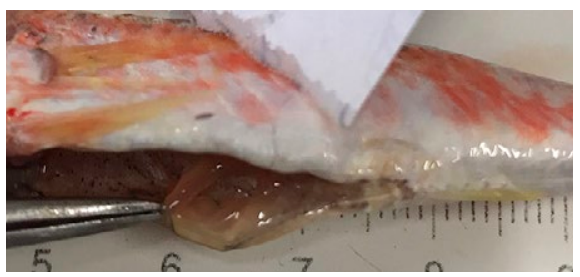

TL 9.0 cm; TW 10 g; ST: November; GSA11

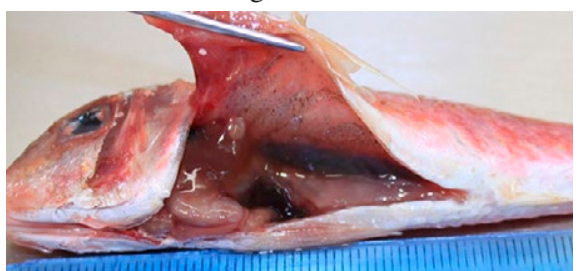

TL 12.0 cm; TW 18 g; ST: November; GSA10-18

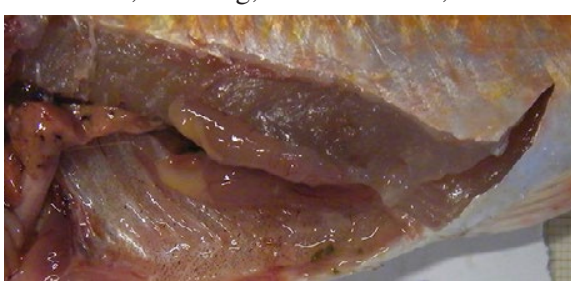

TL 16.5 cm; TW 49 g; ST: February; GSA11

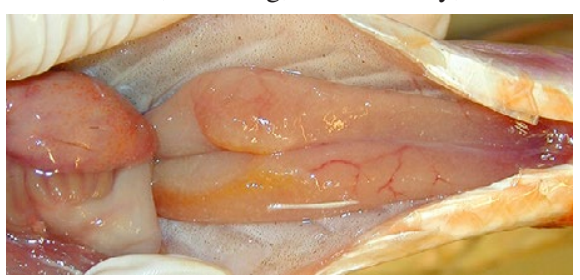

TL 15.5 cm; TW 43 g; ST: May; GSA10-18

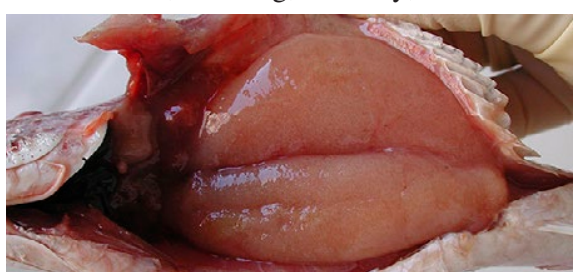

TL 14.4 cm; TW 31 g; ST: June; GSA19

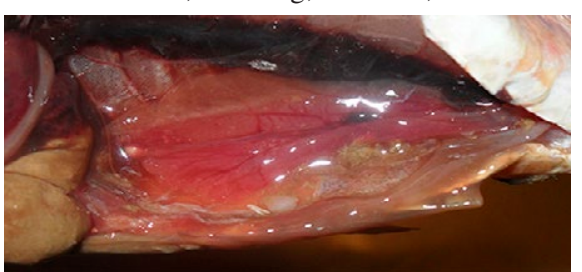

TL 15.0 cm; TW 41 g; ST: August; GSA10-18

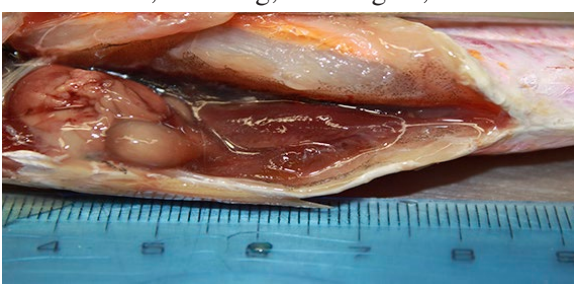

Small pinkish and translucent ovary shorter than $1 / 3$ of the body cavity. Eggs not visible to naked eye.

Small pinkish/reddish ovary shorter than $1 / 2$ of body cavity. Eggs not visible to naked eye.

Pinkish-reddish/reddish-orange and translucent ovary about $1 / 2$ length of body cavity. Blood ked eye.

Ovary pinkish/yellow in colour with granular appearance, about 2/3 length of the body cavity. Eggs are visible to naked eye trough the ovaric tunica, which is not yet translucent. Under light pressure eggs are not expelled.

Ovary orange/pink in colour, with conspicuous superficial blood vessels, From 2/3 to full length of the body cavity. Large transparent, ripe eggs are clearly visible and could be expelled under light pressure. In more advanced conditions, eggs escape freely.

Reddish ovary shrunken to about $1 / 2$ length of the body cavity. Flaccid ovaric walls; ovary may contain remnants of disintegrating opaque and/or translucent eggs.

Pinkish/reddish and translucent ovary. About $1 / 3$ length of body cavity. Eggs not visible to naked eye. 
Table 3. - Description of the microscopic maturity scale of M. barbatus females (H\&E, haematoxylin and eosin).

\begin{tabular}{lll}
\hline Stage & Photos & Gonad description \\
\hline
\end{tabular}

$1-$ Immature $=$ Virgin

$2 \mathrm{~A}-$ Virgin developing

2B - Recovering

2C-Maturing

3 - Mature/Spawner

$4 \mathrm{~A}-$ Spent

4B - Resting

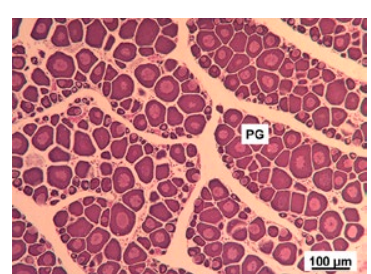

GSA11 (H\&E)

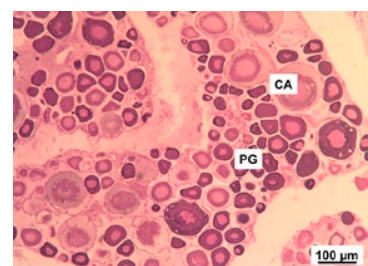

GSA11 (H\&E)

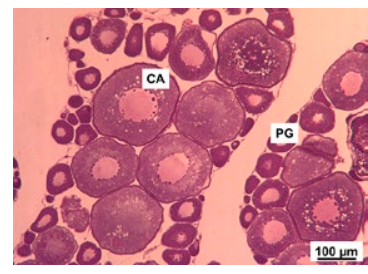

GSA11 (H\&E)

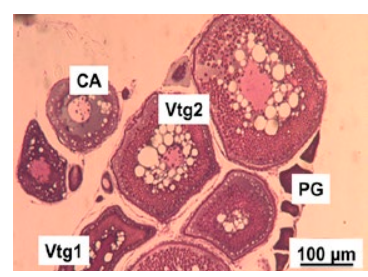

GSA11 (H\&E)

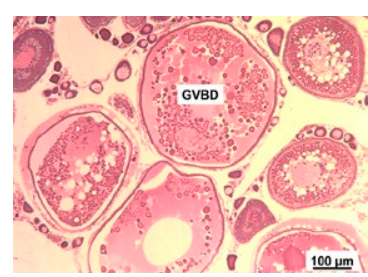

GSA11 (H\&E)

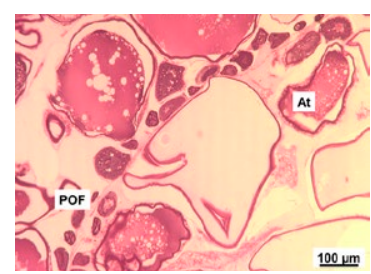

GSA11 (H\&E)

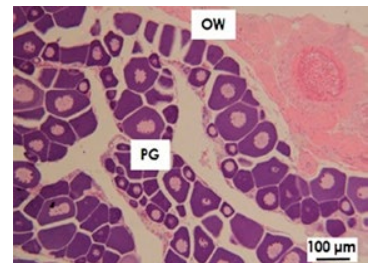

GSA11 (H\&E)
Only oogonia and primary growth (PG) oocytes present. No atresia or muscle bundles. Thin ovarian wall and little space between oocytes.

Cortical alveoli (CA) present. Absence of postovulatory follicles (POFs).

PG and CA oocytes.

Some atretic follicles may be present. Absence of POFs.

Primary (Vtg1) and secondary (Vtg2) vitellogenic oocytes present.

No evidence of POFs or tertiary vitellogenic oocytes .

Tertiary vitellogenic oocytes (Vtg3) or POFs present. Atresia of vitellogenic and/or hydrated oocytes.

GVBD, germinal vesicle breakdown and germinal vesicle migration may be present. Early stage of oocyte maturation (OM) may be present. Only Vtg3, POF and OM can be observed in total spawners.

PG oocytes dominate but some CA and/or Vtg1 and $\mathrm{Vtg} 2$ oocytes are present. Mass of atretic oocytes (At) and POFs present. Thick ovarian wall. Hydrated and overripe eggs may also be present.

Presence of space, interstitial tissue and capillaries around PG oocytes. Thick ovarian wall (OW) and muscle bundles. 
Table 4. - Description of the macroscopic maturity scale of G. melastomus females (TL, total length; TW, total weight; ST, sampling time).

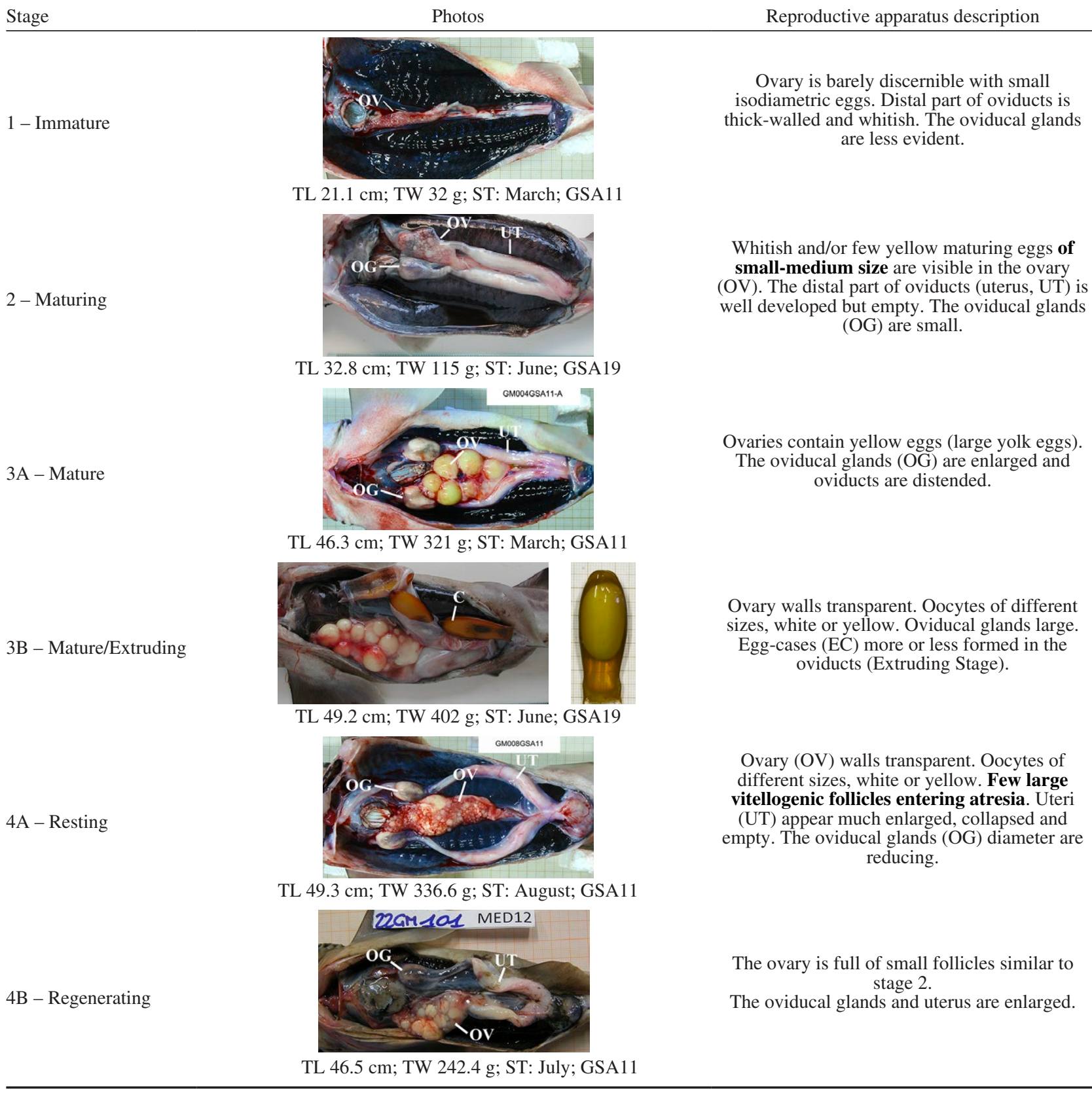
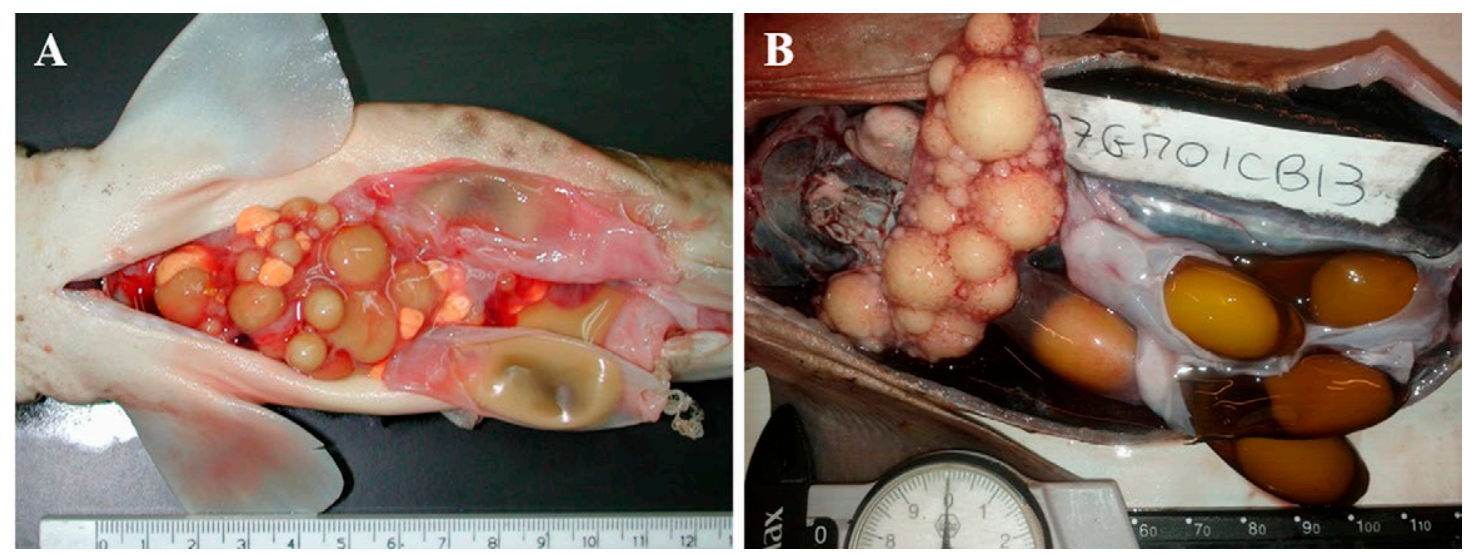

Fig. 2. - Single oviparity in S. canicula (A, $44.3 \mathrm{~cm}$ TL, $315 \mathrm{~g}$ TW, ST, June, GSA 19) and multiple oviparity in G. melastomus (B, $50.6 \mathrm{~cm}$ TL, $436 \mathrm{~g}$ TW, ST, June, GSA 11). 
The resting stage (stage 4a) is characterized by the presence of uteri that have collapsed and reduced in size (compared with the previous stages $3 \mathrm{a}$ and $3 \mathrm{~b}$ ). Also, the oviducal gland appears reduced in dimension. The presence of few but large atresic follicles is the key to the assignment of this stage; in the micro sections postovulatory follicles (POFs) may also be visible (Tables 4-5). In the regenerating stage (stage 4b), the ovary appears enlarged due to the previous ovarian cycle, showing follicles of small to medium size and some large eggs entering in atresia can be also observed. No preovulatory follicles are present in the ovary in this stage. The duration of a possible resting period may be short for most species, i.e. less than one year.
In the immature specimens (stage 1) the ovarian tissue consists of follicles in early pre-vitellogenesis (50-100 $\mu \mathrm{m})$, connected to the germinal epithelium and to the tunica albuginea. The follicular epithelium surrounding the follicle is single and consists mainly of squamous cells, and lipid inclusions are visible in the cytoplasm (Table 5). In the maturing specimens (stage 2) the ovary contains late-formed pre-vitellogenesis follicles in comparison with the previous stage $(\sim 500$ $\mu \mathrm{m}$ ). In the mature specimens (stage $3 \mathrm{a}$ and $3 \mathrm{~b}$ ), the ovary shows follicles in all stages of development, but with a clear predominance of the vitellogenic ones, of high dimensions (up to $3000 \mu \mathrm{m}$ ), showing drops of vitello protein in the cytoplasm (Table 5). Resting

Table 5. - Description of the microscopic maturity scale of G. melastomus females (H\&E, haematoxylin and eosin).

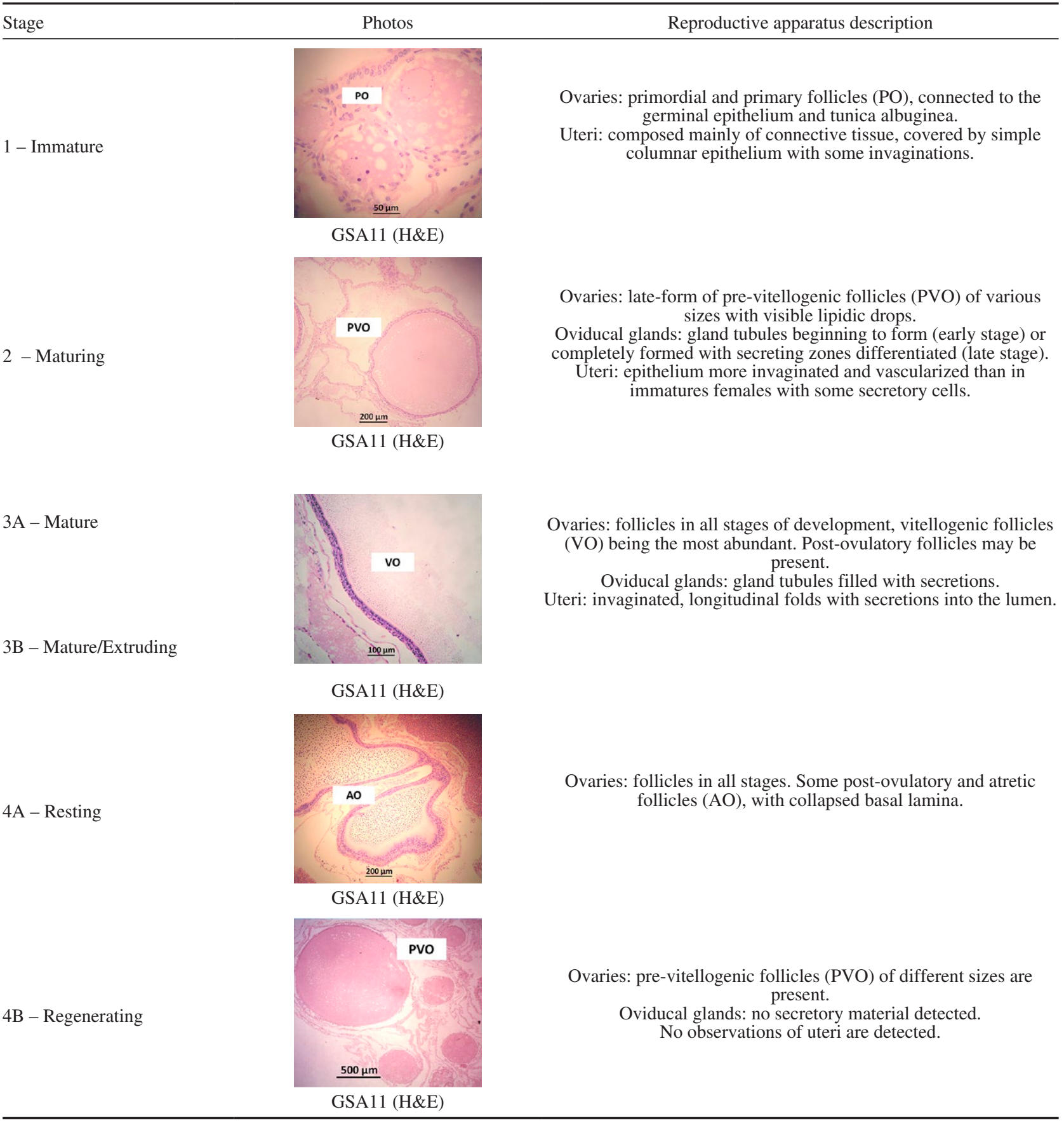


Table 6. - Description of the macroscopic maturity scale of E. spinax females (TL, total length; TW, total weight; ST, sampling time).

\begin{tabular}{lll}
\hline Stage 1 - Immature & Reproductive apparatus description \\
\hline
\end{tabular}

TL 28.3 cm; TW 95 g; ST: January; GSA11

\section{2 - Developing}

$3 \mathrm{~A}$ - Capable to reproduce

3B - Early pregnancy

3C - Mid-pregnancy

3D - Late pregnancy

4A - Regressing

4B - Regenerating

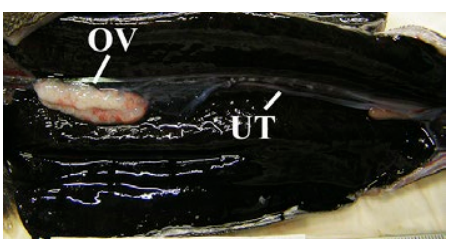

TL 36.0 cm; TW 227 g; ST: November; GSA11

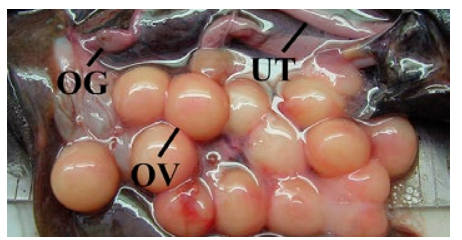

TL 36.5 cm; TW 292 g; ST: January; GSA9

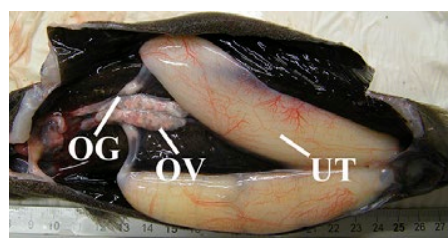

TL 38.0 cm; TW 252 g; ST: November; GSA11
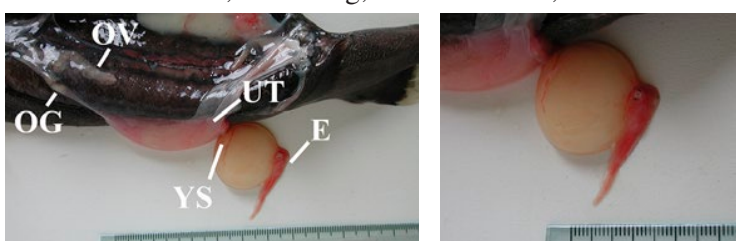

TL 36.0 cm; TW 232 g; ST: June; GSA19
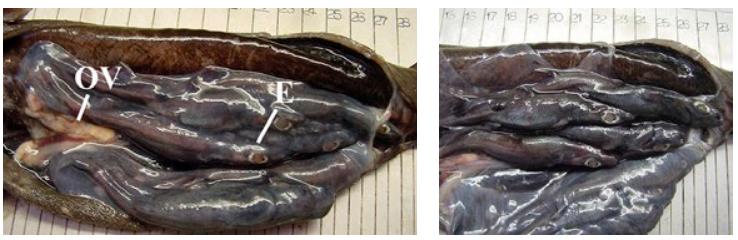

TL 38.0 cm; TW 272 g; ST: January; GSA9

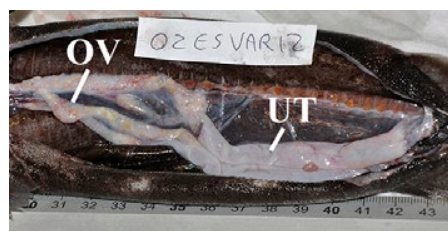

TL 41.1 cm; TW 280 g; ST: November; GSA11

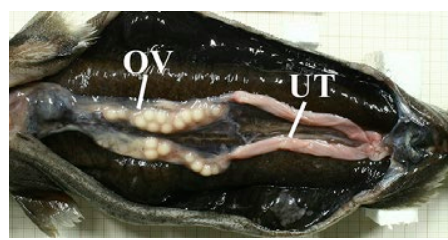

TL 38.5 cm; TW 253 g; ST: November; GSA11
Ovaries (OV) enlarged with small follicles (oocytes) of different sizes. Some larger yellow follicles may be present. Ovaries lack atretic follicles.

Developing oviducal gland and uterus. (UT).

Large ovaries (OV) with enlarged yolk follicles all of about the same size so that they can be easily distinguished. Oviducal gland (OG) and uterus (UT) are developed. Uterus is not dilated and does not contain yolky matter and embryos.

Uteri (UT) well filled and rounded with yolk content (usually candle shape). In general, segments cannot be distinguished and embryos cannot be observed.

Uteri (UT) well filled and rounded, often with visible segments. Embryos (E) are always visible, small and with a relatively large yolk sac (YS).

Embryos (E) fully formed, yolk sacs reduced or absent. Embryos can be easily measured and sexed.

Ovaries (OV) shrunken without follicle development and with atretic (degenerating) follicles. The oviducal gland diameter may be decreasing. Uterus (UT) appears much enlarged, collapsed, empty and reddish.

Ovary $(\mathrm{OV})$ with small follicles in different stages of development with the presence of atretic ones. Uterus (UT) enlarged with flaccid walls. Oviducal gland (OG) distinguishable but reduced in size. 

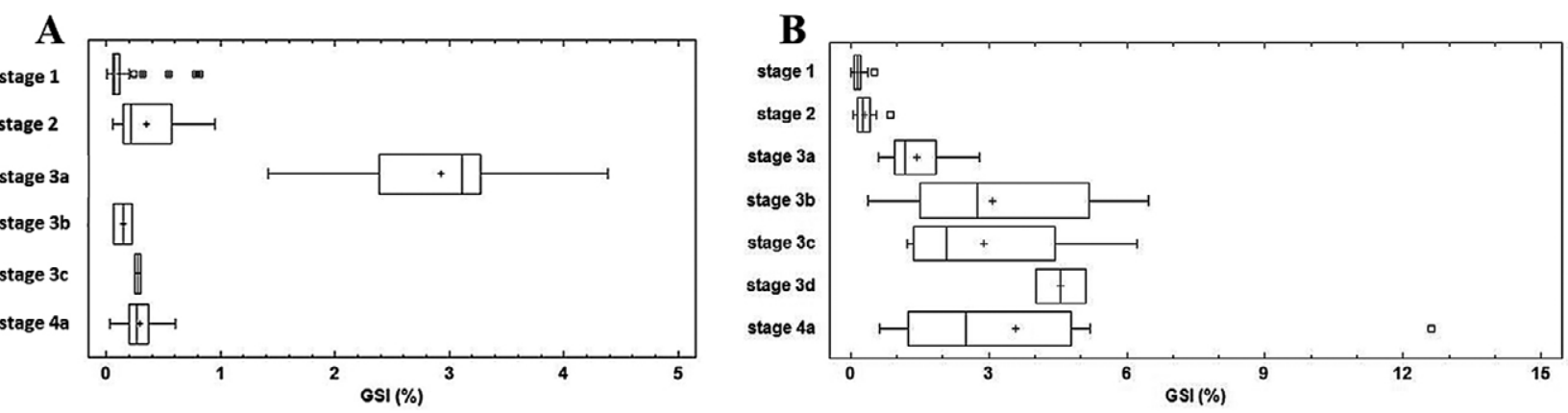

Fig. 3. - Trend of the GSI in (A) E. spinax (asyncronicity between uterine and ovarian phase) and (B) S. blainville (synchronicity between uterine and ovarian phase).

Table 7. - Description of the microscopic maturity scale of E. spinax females (H\&E, haematoxylin and eosin).

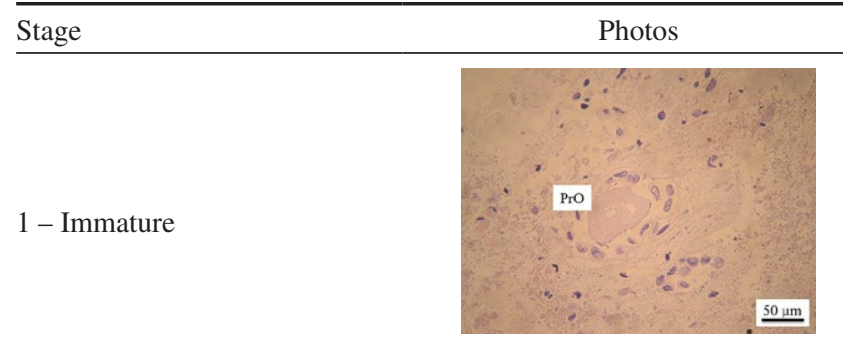

GSA11 (H\&E)

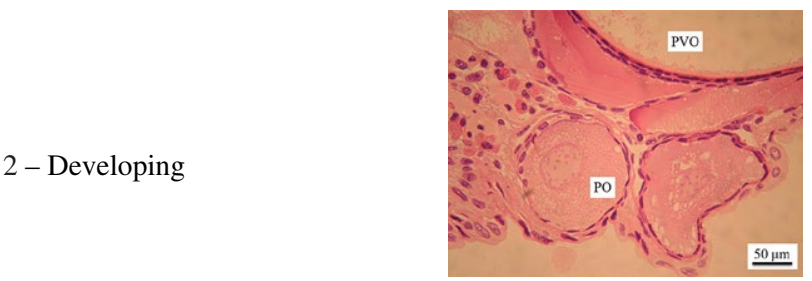

GSA11 (H\&E)

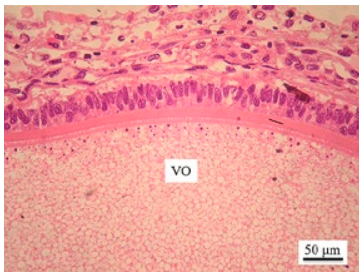

GSA11 (H\&E)

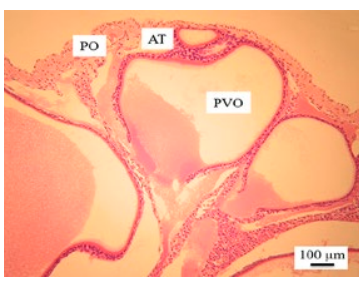

GSA11 (H\&E)
Ovaries: primordial (PrO) and primary follicles, connected to the germinal epithelium and tunica albuginea.

Uteri: composed mainly of connective tissue, covered by simple columnar epithelium with some invaginations.

Ovaries: primordial, primary (PO) and pre-vitellogenic (PVO) follicles of various sizes. Vitellogenic follicles may be present. Oviducal glands: gland tubules beginning to form (early stage) or completely formed with secreting zones differentiated (late stage). Secretions may be observed inside the gland tubules.

Uteri: no observations available.

Ovaries: follicles in all stages of development, vitellogenic (VO) follicles being the most abundant. Post-ovulatory follicles may be present.

Oviducal glands: fully differentiated in four zones. They are filled with secretions in the tubules.

Uteri: no available information.

Ovaries: primary (PO), pre-vitellogenic (PVO), some vitellogenic follicles and atretic follicles (AT) were present (early stages of pregnancy). Ovarian tissue with only primary and pre-vitellogenic follicles observed (final stage of pregnancy).

Oviducal glands: secretory material decreased with the progress of pregnancy.

Uteri: no available information. females (stage 4a) preside post-ovulatory and atretic follicles in which the basal lamina invading the central lumen appears to be collapsed (Table 5). Finally, in females undergoing regeneration (stage $4 \mathrm{~b}$ ) the ovary shows pre-vitellogenic follicles very similar to those found in maturing stage (stage 2). In the case of the oviparous species, the only specimens actually spawning and reproducing in the current year are those from stages 3 to 4 .

\section{Viviparous Elasmobranchii: Etmopterus spinax}

In general, the macroscopic scale of the viviparous species fitted well with what is reported in the MEDITS manual, only few integrations are reported in bold in Table 6 . The macroscale was also confirmed by histological investigations.

In $E$. spinax the macro and micro descriptions of the immature (stage 1) and developing (stage 2) females is 
similar to that reported for the immature and maturing stages of oviparous elasmobranchs (Table $6 \mathrm{cf}$. Table 5).

The vitellogenesis process consists in the formation of yolk drops, in the pseudo-stratification of the follicular epithelium and in an increase in the peripheral vascularization between the technical layers and the follicular epithelium (Table 6) in the egg cell. Yolk droplets begin to form first in the cortical region of the oocyte (CA >1200 microns); later, their size increases and this allows them to fill the entire cytoplasm in mature females. In some primary and pre-vitellogenic follicles (PG and CA) and at the beginning of the vitellogenesis phase the presence of the "lumpbrush" chromosomes was observed in the nucleus (Table 6).

In general, subjectivity in the macroscopic distinction between maternal stages $3 \mathrm{c}$ (mid pregnancy) and $3 \mathrm{~d}$ (late pregnancy) can influence the attribution of the stage. The capability for noticing this differentiation is

Table 8. - Description of the macroscopic maturity scale of A. antennatus females (CL, cephalo-thoracic length; TW, total weight; ST, sampling time).

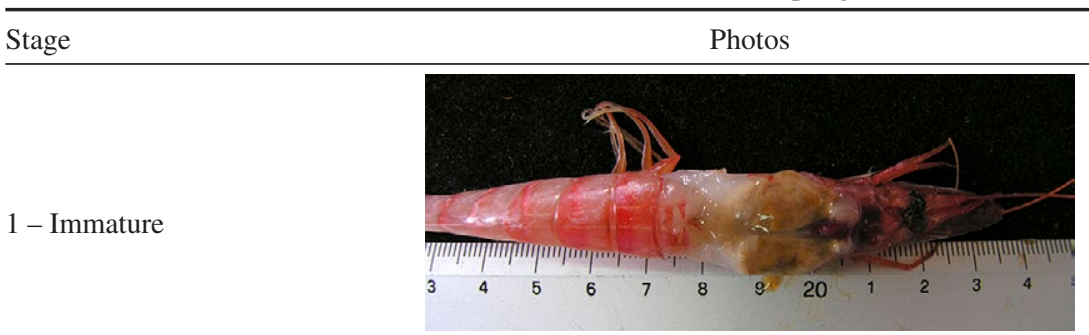

CL 20.3 mm; TW 4 g; ST: March; GSA11

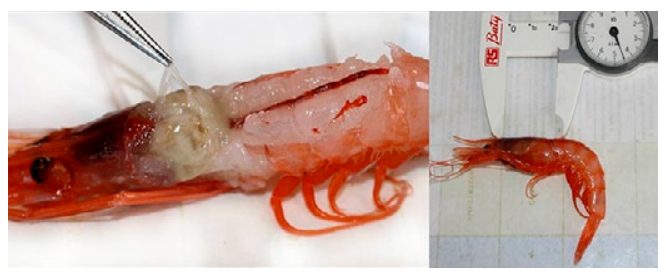

CL 24.0 mm; TW 8 g; ST: June; GSA10

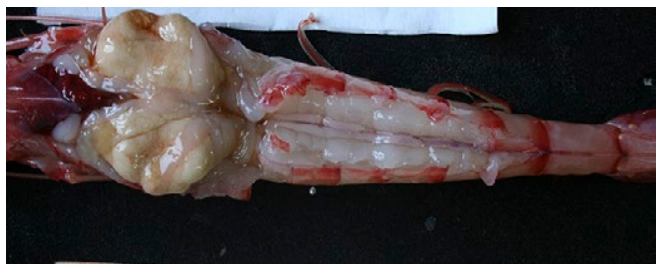

CL 53.6 mm; TW 52 g; ST: May; GSA11

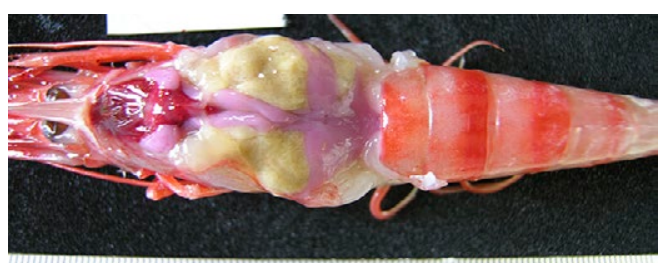

CL 39.2 mm; TW $21 \mathrm{~g} ;$ ST: June; GSA11

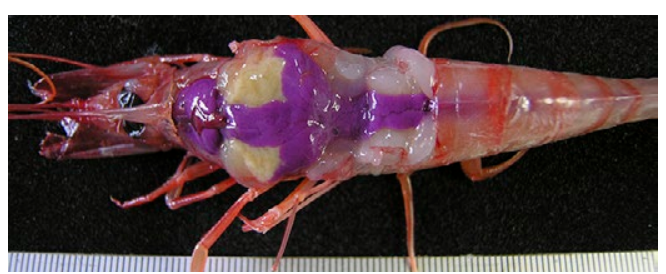

CL 29.8 mm; TW 11 g; ST: June; GSA11

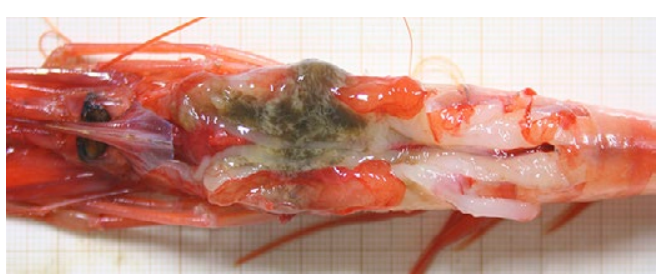

CL 45.7 mm; TW 30 g; ST: September; GSA11
Whitish or translucid ovary hardly visible in transparency. After dissection of the tegument ovary is small and lobes are flaccid, stringy and poorly developed. No spermatophores on thelycum visible.

vory coloured with orange pink violet dotting ovary in development. Cephalic and lateral lobes are small but distinguishable by naked eye. Abdominal extensions are thin and just visible.

Ivory-coloured with orange pink violet dotting ovary in re-development. Cephalic and lateral lobes are small but distinguishable by naked eye. Abdominal extensions are thin and just visible. Occasionally presence of spermatophores.

Lilla-coloured ovary developed and occupies almost entirely the dorsal portion. The cephalic and lateral lobes are much developed and have a turgid consistence.

Turgid violet ovary extends to the whole dorsal portion covering the organs below. Lobes and extensions well developed; in particular, the abdominal extensions are very evident. Oocytes well developed.

Uncoloured resting ovary. Presence of spermatophores. 
Table 9. - Description of the micro maturity scale of A. antennatus females (H\&E, haematoxylin and eosin; TB, toluidine blue).

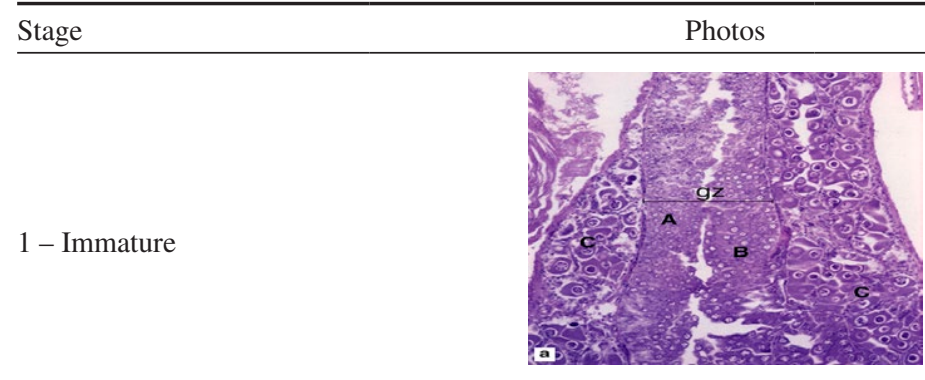

GSA19 (H\&E)

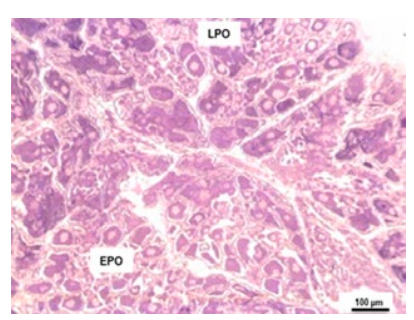

GSA11 $(\mathrm{H} \& \mathrm{E})$

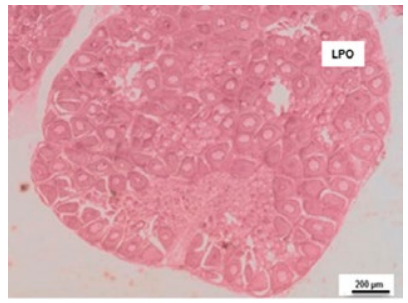

GSA11 (H\&E)

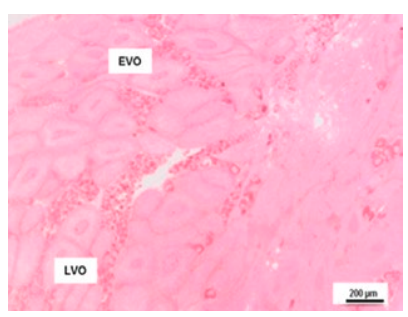

GSA11 (H\&E)

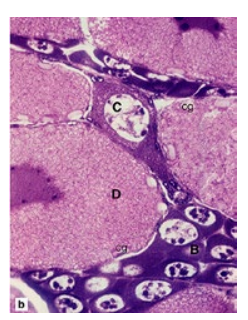

GSA19 (H\&E)

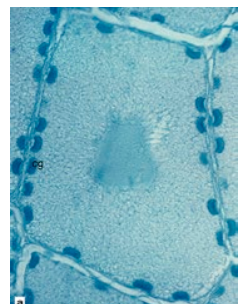

GSA19 (TB)

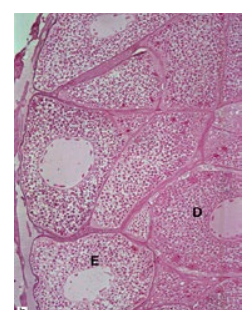

GSA19 (H\&E)

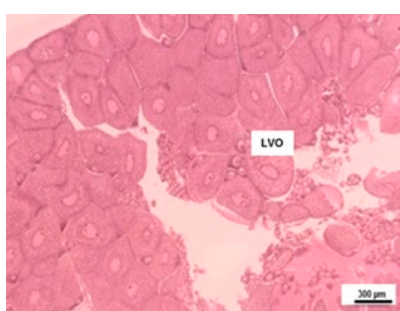

GSA11 (H\&E)

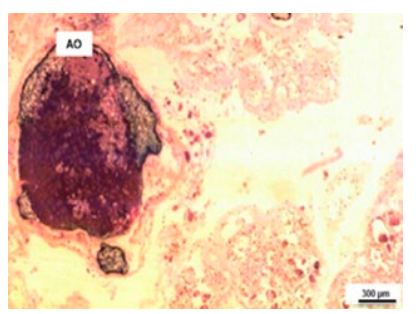

GSA11 (H\&E)
Presence of oogonia and of both early and primary oocytes and occasionally late primary oocytes, scattered around the stroma with no special organization.

The ovarian parenchyma is now structured into a germinative zone containing oogonia and early primary oocytes (EPO)

The maturative zones are organized into lobuli containing late primary oocytes (LPO).

The ovarian parenchyma is now structured into a germinative zone containing oogonia and early and primary oocytes.

The maturative zones are organized into lobuli containing late primary oocytes (LPO).

Besides all the previous cell types, early (EVO) and late (LVO) vitellogenic oocytes are visible in the maturative zone.

Quadrangular EVO oocytes form packet with a mosaic pattern, as they became late vitellogenic oocytes.

In addition to all the previous cell types, advanced LVO may occur. In these cells, the nucleus migrates to the periphery and cortical granules appear.

The ovary tissue appears empty. Residuals of fully mature oocytes can still be seen. Atretic oocytes (AO) are also present. 
Table 10. - Description of the macroscopic maturity scale of $L$. vulgaris females (ML, dorsal mantle length; TW, total weight; ST, sampling time).

\begin{tabular}{lll}
\hline Stage & Photos & Reproductive apparatus description \\
\hline - Immature (virgin) & Ovary semi-transparent, stringy and lacking granular \\
structure (oocytes not visible to the naked eye). Small \\
and translucent nidamental glands (NG) and oviducal \\
gland (OG). Oviduct meander and accessory nidamental \\
glands not visible.
\end{tabular}

2A - Developing

2B - Maturing

3A - Mature

3B - Spent
ML: $14.5 \mathrm{~cm}$; TW: $90 \mathrm{~g}$; ST: July; GSA11

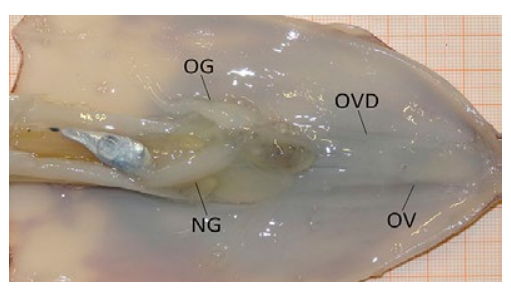

ML 15 cm; TW 103 g; ST: July; GSA11

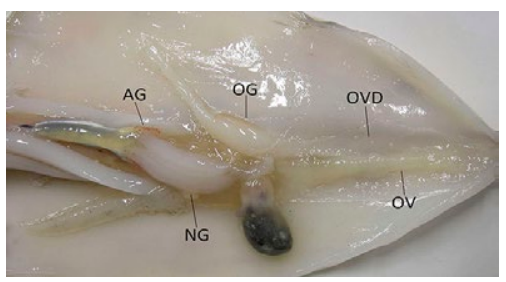

ML 14.6 cm; TW 83 g; ST: July; GSA11

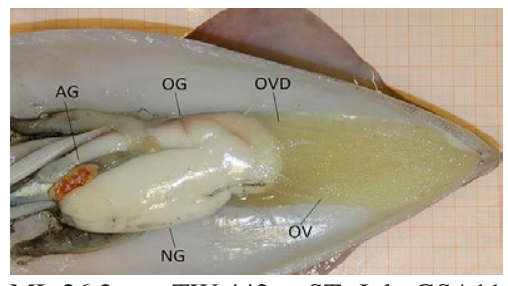

ML 26.2 cm; TW 442 g; ST: July GSA11

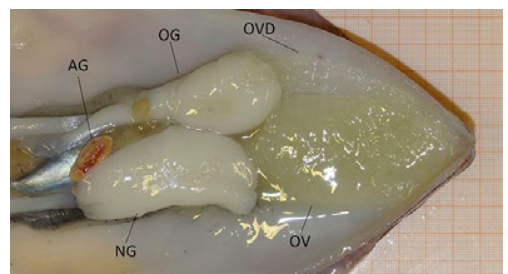

ML 20.5 cm; TW 255 g; ST: July; GSA 11

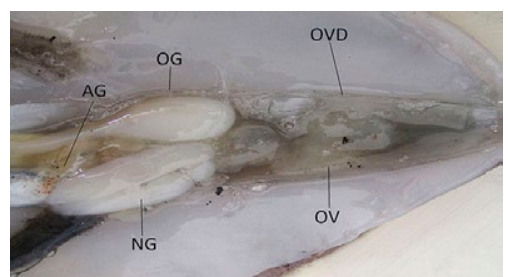

Whitish ovary with visible granular structure (very small oocytes), not reaching the posterior half of the mantle cavity. NG enlarged, covering some internal organs; OG and ovidicut (OVD) meander clearly visible. Accessory nidamental glands not visible.

Ovary occupies the whole posterior half of the mantle cavity, containing tightly packed oocytes (small isodiametric oocytes)

Large NG covering the viscera below. OVD fully developed but empty. OG developed with a lateral brownish strip. Small accessory nidamental glands (AG) visible and lightly red pigmented.

Ovary containing a higher percentage of large oocytes. Enlarged and turgid NG and OG (marked brownish strip). OVD full of amber-coloured oocytes $(\varnothing>=2$ $\mathrm{mm})$. Bright orange-red AG bigger than that of stage $2 \mathrm{~b}$.

Appearance of the organs as above but ovary with a lower number of large oocytes and OVD just emptied or with remains of ripe oocytes.

Flaccid ovary with strikingly loose disorderly aspect. Few oocytes may be attached to the central tissue. Flaccid NG, OG and AG (light pigmented).

ML $21.1 \mathrm{~cm}$; TW $251 \mathrm{~g}$; ST: September; GSA11

only acquired with species-specific experience regarding the state of the yolk sac. In case of difficulties to distinguish between these stages, taking measurements of the embryos is recommended.
It is worth noting that, in the maternal stages the uterus description is not taken into account. However, a distinction among viviparous species between those with synchronicity and those with asynchronicity of uterine and 
Table 11. - Description of the micro maturity scale of L. vulgaris females (H\&E, haematoxylin and eosin).

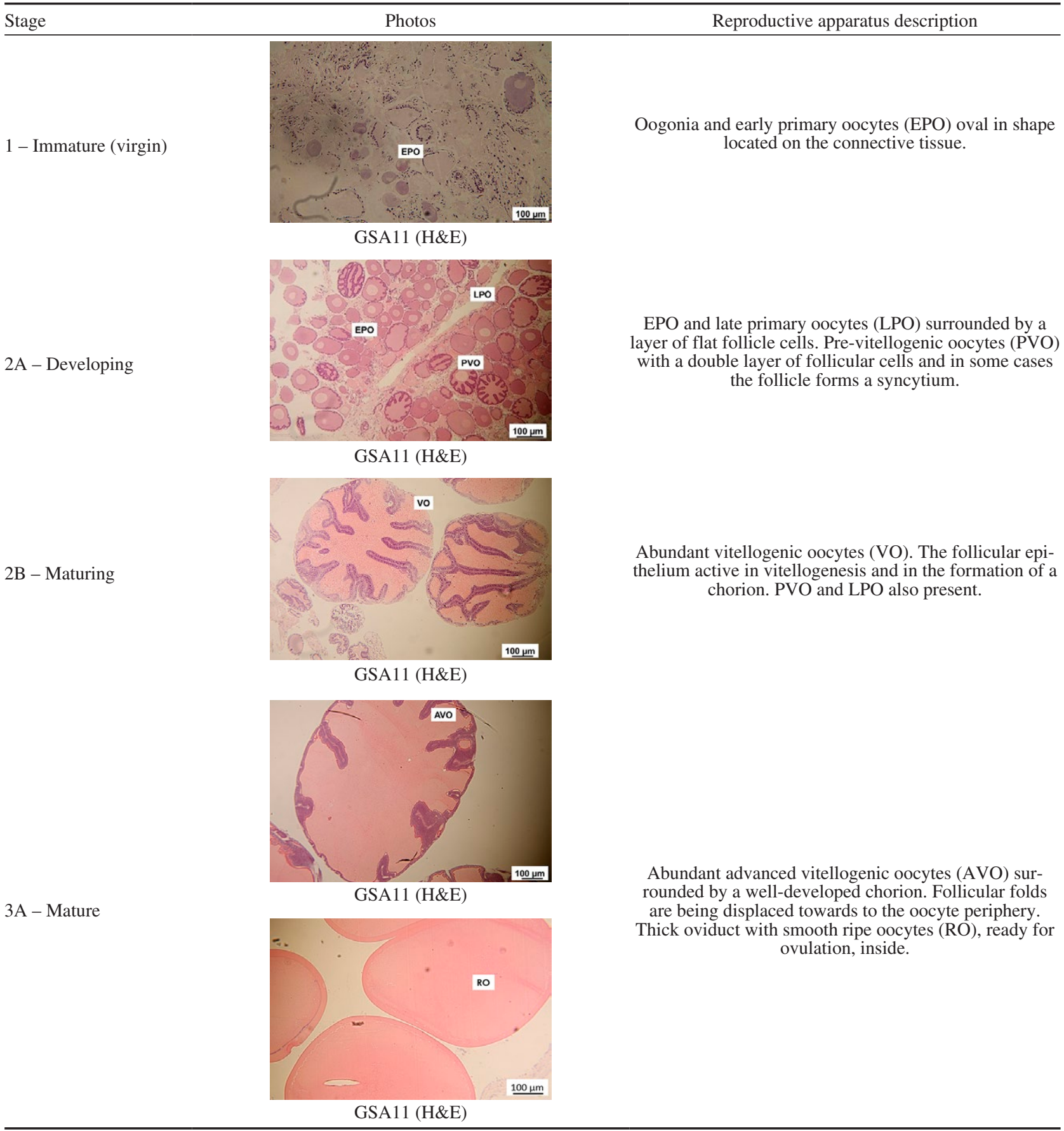

ovarian phases, respectively, should be made. In species such as $E$. spinax with asynchronicity between the two phases, the ovary after stage 3 a begins to regress (Fig. 3 ). While the uteri were developing more and more, the histological sections of the ovaries in stage $3 \mathrm{~b}$ highlighted the presence of primary and pre-vitellogenic follicles surrounded by the epigonal organ with the presence, albeit in a much reduced manner, of some vitellogenic follicles and atretic follicles. Instead, in species with synchronicity such as Squalus blainville (Risso, 1827), the ovary continued its development together with the uterus, as shown by the GSI evolution in each maturity stage (Fig. 2).

In the post-natal phase (stage $4 \mathrm{a}$ and $4 \mathrm{~b}$ ), the ovarian tissue appeared flaccid and contained only primary and pre-vitellogenic follicles (Table 7). No histological information is present for the late maternal and regression stages (3c-3d-4a-4b) (Table 7). In this case, the only specimens actually spawning and reproducing in the current year are those from 3 to 4 .

\section{Crustacea: Aristeus antennatus}

The macroscale of A. antennatus fitted well with what is reported in the MEDITS manual. No integrations are reported in Table 8. The macroscale was also confirmed by histological investigations (Table 9).

Considerable differences in the colour and shape of the ovaries are observed in A. antennatus. The 
aspect of the ovaries varies from transparent, small, duct-like, and restricted at the posterodorsal part of the stomach, to violet, greatly swollen, subdivided into distinct lobes, and covering most of the stomach and hepatopancreas. The primary oocytes and early follicular cells (PG) in immature individuals (stage 1) are very small and with no sign of development. Changes in colour and shape of the ovaries match very well with the development of oocytes moving from oogonia and of both early and primary oocytes (PG, stage 1) to early and late vitellogenic oocytes during the maturing and mature stages (stage $2 \mathrm{c}$ and 3 ). The primary oocytes and early follicular cells in stage 1 are very small and with no sign of development. The high number of nucleoli inside the nucleus of developing vitellogenic oocytes on the maturing ovary indicates that these oocytes have become very active. The enlargement of the expanding oocytes in the mature ovary mainly results from expansion of the cytoplasm, which has become acidophilic, probably indicating the presence of yolk droplets, vitellogenic and/or glycoprotein substance. In the resting adult (stage $2 \mathrm{e}$ ), the presence of atretic oocytes is also detected. Macroscopically, the ovaries appear ivorycoloured with cephalic and lateral lobes small but distinguishable to the naked eye. In these stages the maturative zones are organized into lobuli containing late primary oocytes. The only specimens actually spawning and reproducing in the current year are those from stages 2 to 5 .

\section{Cephalopoda: Loligo vulgaris}

The reproductive apparatus changes from its immature condition characterized by small dimen- sion, translucid appearance and absence of oocytes, to a full maturity status (stage 3a) through two distinct phases of developing (stage $2 a$ ) and maturing (stage 2b) (Table 10). Stage $2 \mathrm{~b}$ is distinguished from the previous $2 \mathrm{a}$ by the larger size of the organs and also by the presence of a lateral brownish strip on the oviducal glands and the appearance of small, slightly red pigmented, accessory nidamental glands. The following fully maturity (stage 3a) is unequivocally defined by enlarged and turgid glandular structures but principally by the presence of a higher percentage of large oocytes in the ovary and ripe oocytes $(\varnothing>=2 \mathrm{~mm})$ inside the oviduct. Moreover, a markedly lit colour of the oviducal gland lateral strip and of the accessory nidamental gland can be observed.

As shown in Table 10, the ovary in mature phase could also include fewer oocytes and/or a just emptied oviduct. Stage $3 \mathrm{a}$ is clearly distinguished from stage $3 \mathrm{~b}$ (spent) because, in the latter, the organs showed a disorderly and flaccid appearance.

From a histological point of view (Table 11), it is possible to observe the presence of different cells resulting from the oogenesis and their different proportion characterizes the five stages. In particular, the differences between the developing stage (stage 2a) and the maturing stage (stage $2 b$ ) are given by the appearance of late primary oocytes and vitellogenic oocytes, respectively. In the mature stage, vitellogenic oocytes are prevalent in the ovary and are displacing their follicular folds towards to the periphery to be ready for ovulation like the smooth ripe oocytes visible inside the oviduct. The only cephalopods actually spawning and reproducing in the current year are those from stages $2 \mathrm{~b}$ to $3 \mathrm{~b}$.
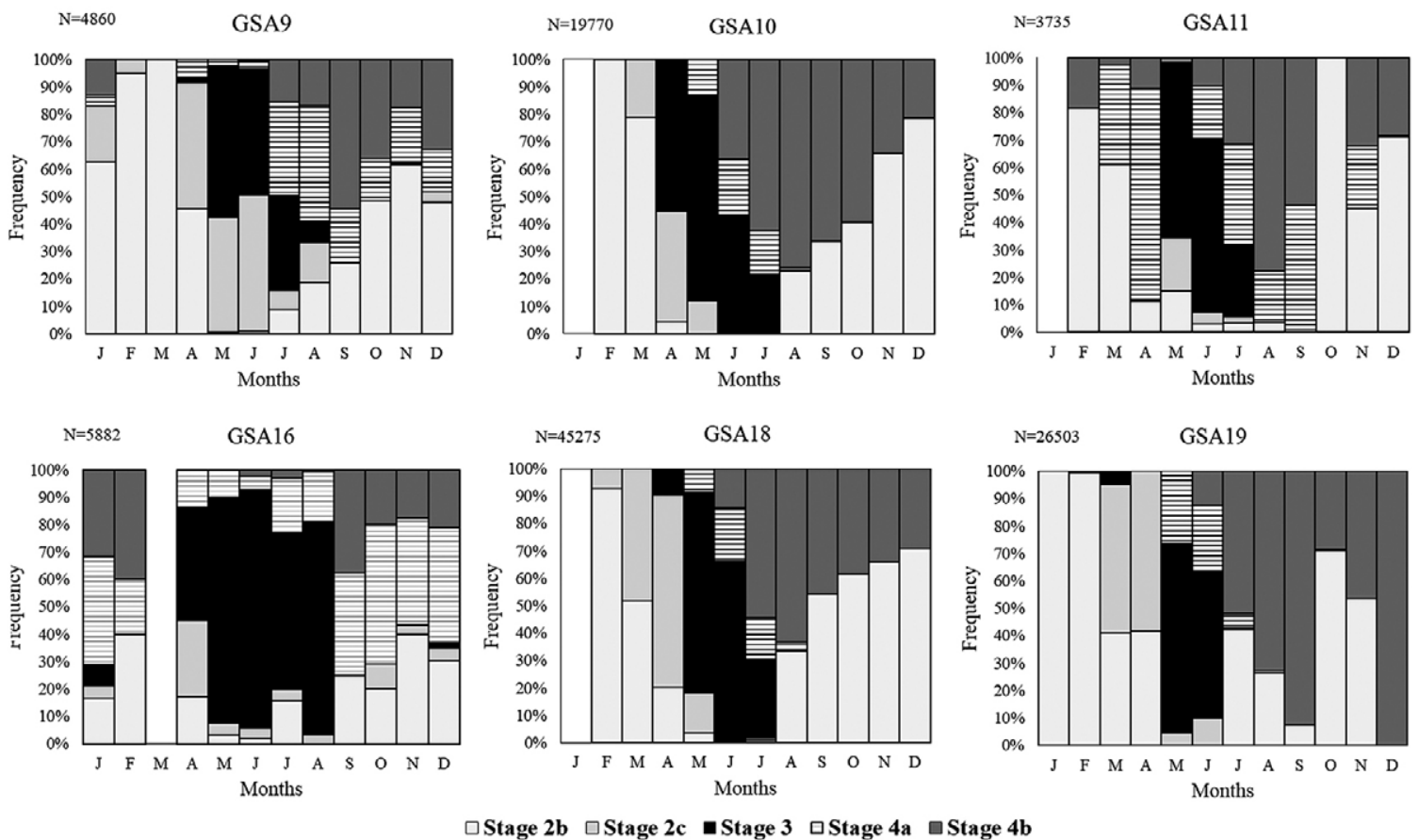

Fig. 4. - Monthly distribution of M. barbatus females at each gonadal phase during the sampling period in different GSAs. The different shades of grey indicate mature individuals. 

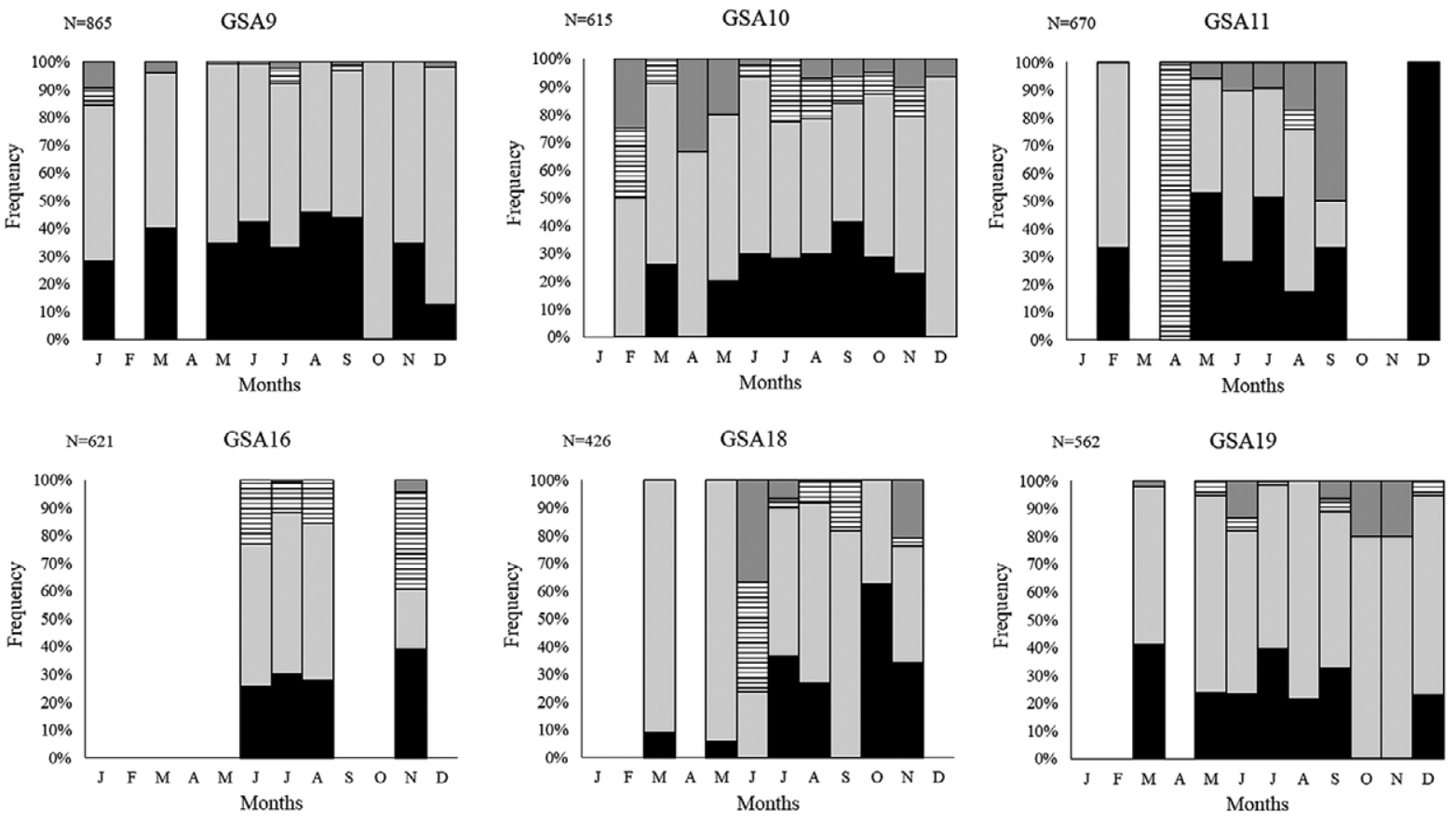

- stage 3a $\square$ stage 3b $\quad$ घstage 4a $\square$ stage 4b

Fig. 5. - Monthly distribution of G. melastomus females at each gonadal phase during the sampling period in different GSAs. The different shades of grey indicate mature individuals.
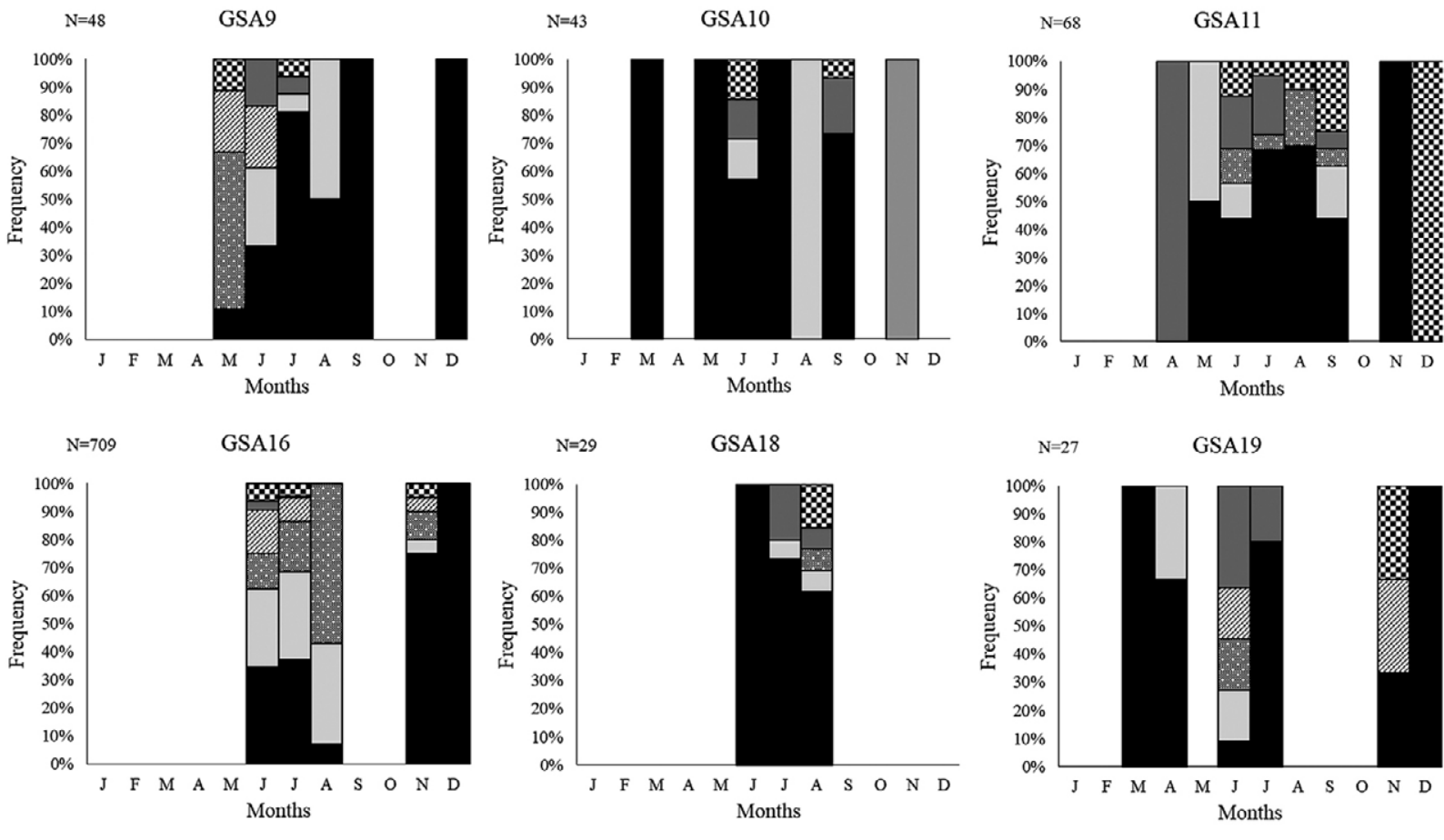

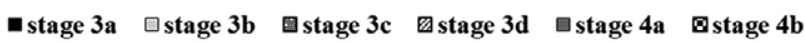

Fig. 6. - Monthly distribution of E. spinax females at each gonadal phase during the sampling period in different GSAs. The different shades of grey indicate mature individuals.

\section{Biological data}

In general, a similar reproductive period of the species is observed between the geographic areas studied (Figs 4-8). Red mullet females showed a reproductive period from April to July with a code in early autumn in all GSAs considered. The peak of the spawning period seems to be concentrated in May-July in GSAs 9-11-18-19, whereas it appears just more extended from April to July in GSA 10 and from April to August in GSA 16 (Fig. 4).

The reproductive season of the viviparous E. spinax and the oviparous G. melastomus occurs all year around in all the investigated GSAs. Specifically, ma- 

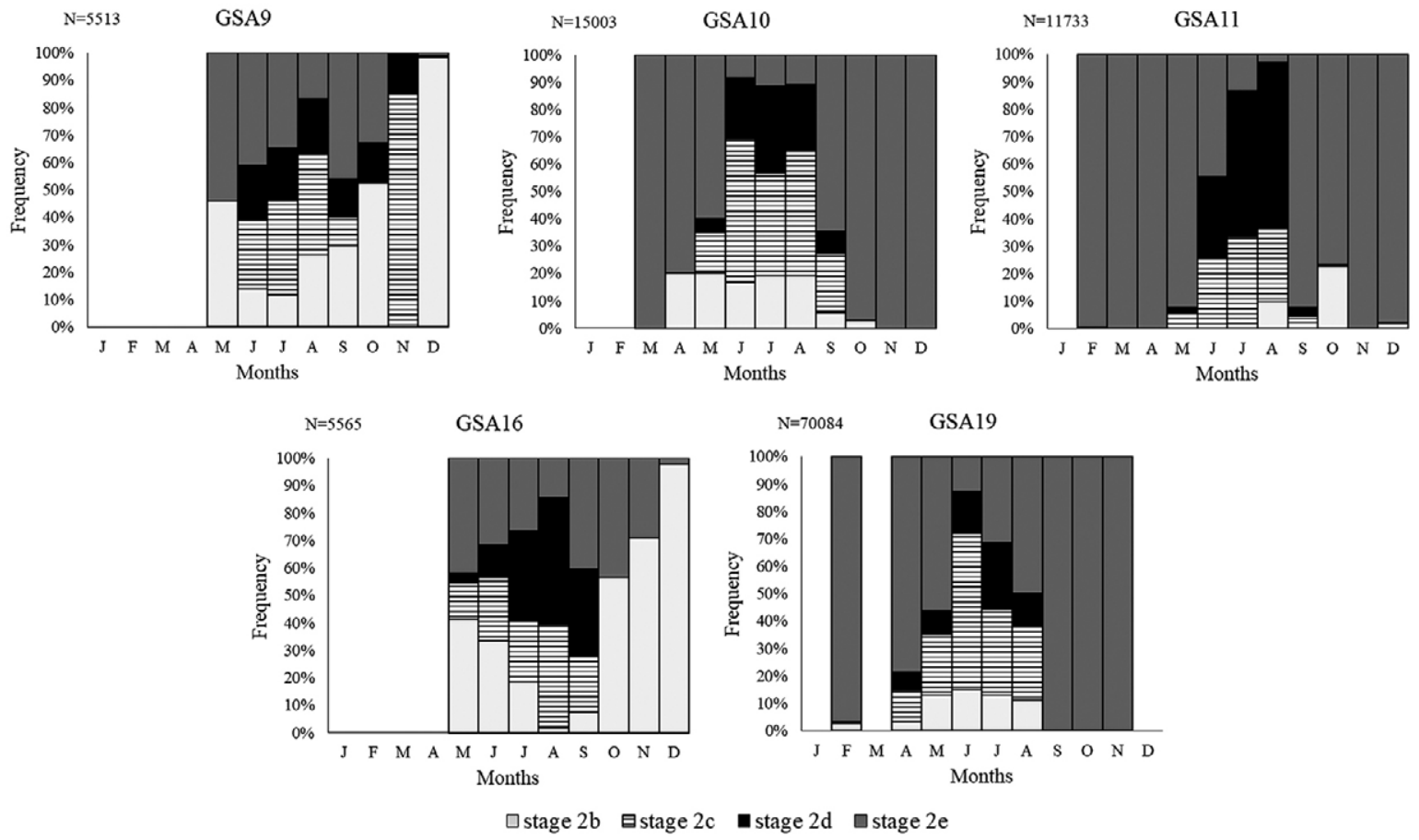

Fig. 7. - Monthly distribution of A. antennatus at each gonadal phase during the sampling period in different GSAs. The different shades of grey indicate mature individuals.
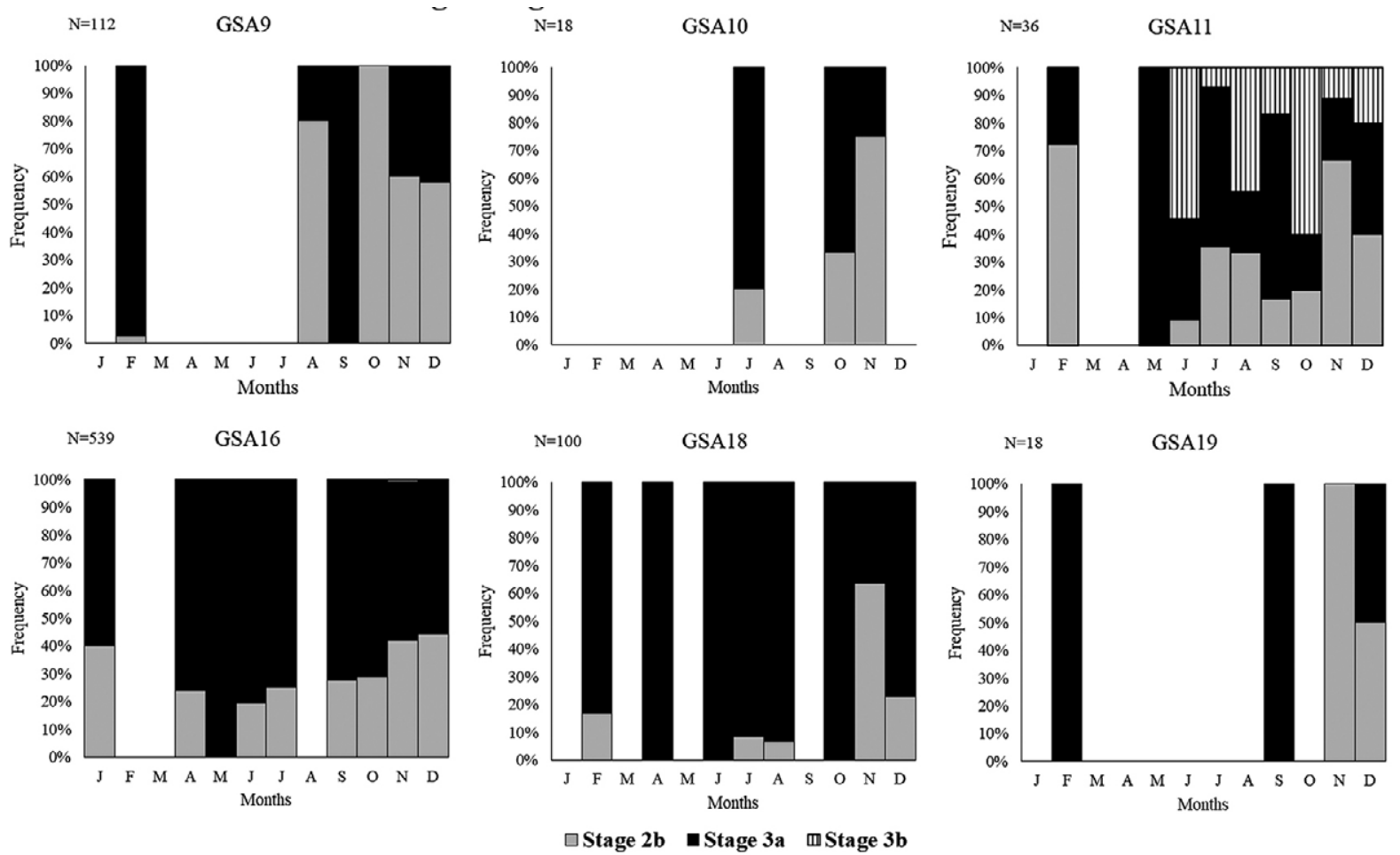

Fig. 8. - Monthly distribution of L. vulgaris at each gonadal phase during the sampling period in different GSAs. The different shades of grey indicate mature individuals.

ture (stage 3a) and pregnant individuals (stages 3b, 3c) of $E$. spinax were found mainly in summer and autumn while mature females (stage 3a) of G. melastomus were found all year around but with low frequencies (Figs. 5-6). The spawning time of $A$. antennatus is comprised between spring and summer period in all analysed GSAs (Fig. 7). Although L. vulgaris is not well repre- sented monthly in all GSAs, its spawning period seems to occur all year in all investigated areas (Fig. 8).

The $\mathrm{SFM}_{50}$ of $M$. barbatus in GSAs 10,18 and 19 shows values of about $11 \mathrm{~cm}$ TL. The highest $\mathrm{SFM}_{50}$ value was registered in female population of Ligurian Sea (GSA9, $13 \mathrm{~cm} \mathrm{TL}$ ) and the lowest one in Sardinia (GSA11, $10.77 \mathrm{~cm} \mathrm{TL})$ (Table 12). 
The $\mathrm{SFM}_{50}$ of E. spinax ranges from 32.0 to 36.0 $\mathrm{cm}$ TL, with the lowest values in GSAs 9 and 18 and the highest ones in GSAs 11 and 19. G. melastomus females attained the $\mathrm{SFM}_{50}$ at the same length [between $45.16 \mathrm{~cm}$ (GSA 10) and $46.59 \mathrm{~cm}$ TL (GSA 19)], except for the Ligurian population with the lowest $\mathrm{SFM}_{50}$ observed $(41.80 \mathrm{~cm}$ TL).

The $\mathrm{SFM}_{50}$ of $A$. antennatus ranges from a minimum of $21.88 \mathrm{~mm}$ CL in GSA 11 to a maximum of $25.67 \mathrm{~mm}$ CL in GSA 19. In general, in the whole Tyrrhenian the values are around 23.0-24.0 mm CL, while in the Ionian Sea a higher value was recorded (25.67 $\mathrm{mm}$ CL). Finally, L. vulgaris shows values ranging from 14.44 in the southern Adriatic to 17.92 in Sardinia (Table 12).

\section{DISCUSSION}

Knowledge on sexual maturation process of a species is vital in understanding its life cycle and can play a key role in its assessment. With this information, fishery assessment scientists can provide estimates for a given species (e.g. onset of maturity by length and age), characterize the life cycle identify recruits, juveniles, adults, pregnant, etc., determine the duration of egg-laying/pregnancy/gestation periods and monitor long-term changes in the reproductive strategy (estimating fecundity, energy budget allocation and maturity-survival-longevity tradeoffs. etc.) (ICES 2013). Furthermore, maturity scales represent a useful tool for evaluating the sexual maturity process, even if it means dividing it into stages, imposing an artificial discontinuity onto what is in reality a continuous process (ICES 2010).

Basically, the creation of a maturity scale is not easy and it is often complicated to decide how many steps should be included; this obviously depends on the use of the scale and of the aims of the research (Cuccu et al. 2013). Currently, the literature presents a confusing number of macroscopic maturation scales for fish, cephalopods and crustaceans, varying from over-simplified scales comprising three to four stages to highly specific and relatively complicated nine-stage scales (ICES 2007).

The standardization of maturity stage classification is fundamental when stock assessment is based on several institutes' data. In order to estimate new maturity ogives, all institutes involved in stock assessment should use the same criteria to distinguish immature and mature specimens.

In this paper, thanks to the opportunity of having maturity gonad data collected from different countries taking part to the MEDITS programme, we tried to made an analysis of the maturity scales used inside the project for the determination of gonad maturity stages of teleostean, elasmobranch, crustacean and cephalopod females. The analysis was done taking into consideration the correspondence between key histological processes of development and corresponding modifications observed at the macroscopic level. In general, the macroscopic stage description in the different scales fitted well with what discriminated at
Table 12. - Size at first maturity $\left(\mathrm{SFM}_{50}\right)$ and relative standard error $\left(\mathrm{SE} \mathrm{SFM}_{50}\right)$, maturity range $(\mathrm{MR})$ and relative standard error $\left(\mathrm{SE} \_\mathrm{MR}\right) . \mathrm{Size}=$ total length $(\mathrm{cm})$ for fish, cephalo-thoracic length $(\mathrm{mm})$ for crustaceans, dorsal mantle length $(\mathrm{cm})$ for cephalopods.

\begin{tabular}{lccccc}
\hline Species & GSA & SFM $_{50}$ & $\begin{array}{c}\mathrm{SE}_{-} \\
\mathrm{SFM}_{50}\end{array}$ & MR & SE_MR \\
\hline M. barbatus & 9 & 13.00 & 1.00 & 1.53 & 0.14 \\
& 10 & 11.59 & 0.01 & 0.63 & 0.01 \\
& 11 & 10.77 & 0.08 & 1.10 & 0.10 \\
& 16 & 12.15 & 0.29 & 1.24 & 0.02 \\
& 18 & 11.81 & 0.01 & 0.63 & 0.01 \\
E. spinax & 19 & 11.17 & 0.01 & 1.19 & 0.02 \\
& 9 & 32.95 & 0.99 & 2.73 & 0.95 \\
& 10 & 34.74 & 1.07 & 1.69 & 1.29 \\
& 11 & 36.39 & 0.47 & 3.13 & 0.62 \\
G. melastomus & 18 & 32.29 & 0.79 & 1.14 & 0.92 \\
& 19 & 36.59 & 0.59 & 3.38 & 0.71 \\
& 10 & 41.80 & 0.99 & 1.92 & 1.26 \\
& 11 & 45.16 & 0.41 & 2.42 & 0.56 \\
A. antennatus & 18 & 46.59 & 0.71 & 2.45 & 0.89 \\
& 19 & 45.70 & 0.19 & 2.89 & 0.25 \\
& 9 & 23.10 & 1.40 & 2.03 & 0.07 \\
& 10 & 24.15 & 0.10 & 0.33 & 0.10 \\
& 11 & 21.88 & 0.35 & 0.57 & 0.37 \\
L. vulgaris & 18 & 24.02 & 0.16 & 0.56 & 0.19 \\
& 19 & 25.67 & 0.01 & 0.14 & 0.01 \\
& 9 & 14.87 & 1.00 & 1.06 & 0.30 \\
& 11 & 17.92 & 0.27 & 2.16 & 0.30 \\
& 16 & 15.43 & 0.29 & 0.93 & 0.02 \\
& 18 & 14.44 & 0.19 & 1.70 & 0.18 \\
& 19 & 16.27 & 0.20 & 0.62 & 0.19 \\
\hline
\end{tabular}

histological level. Only a few specifics are added in the existing tables. However, as for elasmobranch species, the analysis of the ovary aspect alone is not sufficient to determine the correct maturity stage. As reported in the last ICES report (ICES 2013), the development of other reproductive organs such as the oviducal glands and the uteri are crucial for discerning maturity stages that can be easily confused, such as stage 2 (regarding a virgin female in a maturing phase) vs stage $4 \mathrm{~b}$ (regarding a mature non-virgin specimen in a regenerating phase and ready for another cycle). Furthermore, in viviparous specimens, it is determinant to distinguish species with an asynchronous (e.g. E. spinax) (Porcu et al. 2014) or synchronous (e.g. S. blainville) development of the ovaries in comparison with the uteri during maternal phases, in order to ensure a proper identification of maternal stages, especially in the postpartum phases. In these stages, the uteri aspect plays an important role in discerning a mature female ready to undertake the maternal phases (uteri are turgid) from a female in regressing or regenerating phases (with enlarged and flaccid or a partially flaccid uteri).

For cephalopod species, various more or less detailed scales have been developed in relationship to the three types of female reproductive systems characteristic of octopods, squids and cuttlefish (e.g. Lipinski 1979, Juanicó 1983, ICES 2010). Moreover, a further diversity can be observed within squids (Arkhipkin 1992), where only one oviduct and two accessory nidamental glands are developed in some species (e.g. L. vulgaris and L. forbesii) and two oviducts and no accessory glands in others (e.g. Illex coindetii, Todaropsis eblanae, Todarodes sagittatus). Regarding $L$. vulgaris, a more extensive and thorough description also of the secondary sexual structures, as proposed in 
this paper, could help in the attribution of the maturity stages, avoiding any ambiguity, especially on board. As already observed for the oviducal gland in the common octopus Octopus vulgaris (Cuccu et al. 2013), for the loliginid squids the features of the oviducal gland and of the accessory nidamental ones could allow greater accuracy in the macroscopic evaluation of maturity. For example, the attribution of the two stages $2 \mathrm{a}$ and $2 \mathrm{~b}$ (histologically distinct), which in the current scale is based on the arbitrary evaluation of the size and level of development of the glandular structures, could be facilitated by observing the accessory glands pigmented and the brownish lateral strip in the oviducal gland, features present only in stage $2 \mathrm{~b}$. The difficulty of sampling spent females or ones in advanced spawning that is common in cephalopods does not help to determine whether the species is a total or partial spawner or to estimate the duration of the process. Regarding the spawning period of the analysed species, it emerged that, even if mature females of $L$. vulgaris are found throughout the year, the bulks are found in autumn-winter, a period that does not match with the MEDITS survey season. In general, the more or less rapid growth as a result of the different hatching season leads specimens to reach sexual maturity at different sizes, thus justifying the variability of data recorded in the geographical areas investigated.

Generally, when maturity data are used for maturity ogive estimation, one important issue should be taken into consideration: the possible macroscopic misclassification of resting females as immature (ICES 2015, Carbonara et al. 2015). Specifically in teleosteans, the difference between resting and recovery is sometimes unclear, and apparently means the same thing for researchers who consider recovering (or regenerating) or resting as a single stage. However, recovering is merged with developing in some crustacean female macro scales, and resting is merged with immature stage in hake, sardine and anchovy macroscales (ICES 2009b). In summary, there is no single pattern for these stages because they are macroscopically hard to distinguish. In all these cases, if the misclassification of different stages is applied when we are calculating a maturity ogive, an overstimation of $\mathrm{SFM}_{50}$ is observed (Dominguez-Petit 2007). In order to avoid classifying resting individuals as immature, it is most important to use individuals collected during the peak of the reproductive season, when resting individuals are scarce. Indeed, in females of some species, distinguishing between immature and resting (specimens outside the breeding season) may prove difficult. The inaccurate classification translates into many ups and downs in the correct size of the logistic curve of maturity (i.e. the size above the $50 \%$ level of mature individuals) instead of a smooth curve. To avoid such classically occurring pitfalls, the size and age at first maturity must be determined in samples collected during the pick of the breeding season whenever possible. Otherwise, these important parameters will likely be overestimated $(\mathrm{Nu}-$ ñez and Duponchelle 2009).

For the red mullet, the immature specimens are rare/ lacking during the spawning period because they reach the first maturity in the first years of life (Carbonara et al. 2015). This pattern of maturing/growth makes it difficult to estimate $\mathrm{SFM}_{50}$ only with data collected during the spawning period. Then, the MEDITS macroscopic scale, which includes the distinction between the recovering (adult) and virgin developing (juveniles) stages, can produce reliable estimation of $\mathrm{SFM}_{50}$.

During the regenerating phase within the reproductive cycle, only histology can be helpful for producing reliable results and not without difficulties (Junquera and Saborido-Rey 1996). Both immature and mature regenerating females (i.e. fish with undeveloped ovaries prior to recrudescence in the next reproductive cycle) have primary growth oocytes as their most developed oocyte stage. Similarly, both first-time spawners and repeat spawners will develop cortical alveolar oocytes early in their reproductive cycles. Because of this, additional histological features are often used to help distinguish between immature and mature regenerating females, including thickness of the ovarian wall (Morrison 1990), lamellar structure, the presence of very-late-stage atretic oocytes, the presence of melanomacrophage centres, and muscle bundles. The thickness of the ovarian wall is expected to be greater in mature females that have expanded and contracted their ovaries in past reproductive cycles (Fig. 2). However, this trait can be difficult to quantify because histological slides are often made from partial cross sections of the ovary, meaning that the ovarian wall is no longer representative of its state in situ. In addition, the thickness of the ovarian wall is highly variable even in a full cross section, making it difficult to obtain a representative measurement.

On the other hand, a reduction in $\mathrm{SFM}_{50}$ may be indicative of overexploitation of stock and/or a decrease in stock reproductive potential (Carbonara et al. 2015). This is because smaller females begin ovary development at a later time and will probably be in spawning condition later (Kjesbu 1994). These females will produce not only less but also smaller eggs (Kennedy et al. 2007) during a shorter spawning season and a less intense reproductive activity (Alarcón et al. 2004), which will result in smaller larvae (Carbonara et al. 2015) with less probability of surviving and being recruited to the SSB (Cardinale and Arrhenius 2000). Moreover, an increase or decrease in $\mathrm{SMF}_{50}$ may affect the assessment results and, subsequently, management measures (Marshall et al. 2003, Tomkiewicz et al. 2003, Dominguez-Petit 2007).

The reproductive periods of key selected species, estimated through the monthly evolution of macroscopic maturity stages, are in general in agreement with those already reported in literature for the Mediterranean Sea (e.g. Pesci 2006, Carbonara et al. 2015). In particular, the red mullet females seem to reproduce during the summer months in all GSAs except for GSA 16, where few mature specimens are observed also in December and January. As regards G. melastomus, the reproductive period, extending to the whole year in the analysed GSAs, is in line with the data reported for all Mediterranean areas (e.g. Tursi et al. 1993, Ragonese et al. 2009, Marongiu et al. 2013). For all investigated 
areas (except for Sardinian seas, Porcu et al. 2014), data on reproductive period of velvet belly lanternshark females are shown for the first time. The species seems to reproduce all year around, with pregnant specimens mainly observed during spring and summer. The spawning periods of $A$. antennatus females, observed in all GSAs (spring and summer) investigated, are in agreement with those reported in literature for the different areas (e.g. Follesa et al. 1998, D'Onghia et al. 2005, Casciaro et al. 2012). Finally, L. vulgaris reproductive data (a long spawning period, all year around) are in line with the literature (e.g. Agus 2015) in all analysed areas.

The $\mathrm{SFM}_{50}$ calculated in this work, thanks to the same maturity scales per species and same procedure, show similar trends, highlighting that no difference exists among GSAs. Indeed, survey data, differently from commercial ones considered important to obtain maturity ogives of species with a protracted spawning season, have advantages because they are collected under more controlled conditions from a known design. Moreover, considering that in stock assessment models maturity ogives have no effect on the estimates of stock numbers but directly on the assessment process through the calculation of SSB, care must be taken in their calculation. Indeed, once the SSB has been calculated, assessments use it to make forecasts, set biological reference points through the stock-recruitment relationship and judge where the stock is in relation to these reference points.

In conclusion, it appears fundamental to define standardized maturity scales suitable for different systematic classes in order to highlight some specifics that are useful for calculating reproductive parameters. In fact, the accuracy of the correct maturity stage attribution could be particularly suitable in the calculation of the ogives and in the definition of any other reproductive items.

\section{ACKNOWLEDGEMENTS}

The MEDITS surveys have been carried out within the Data Collection Framework. The European Commission and Member States of the Mediterranean countries are thankfully acknowledged. We are also grateful to all th e colleagues who have spent effort and time in collecting and classifying the gonads during the MEDITS surveys.

\section{REFERENCES}

Anonymous. 2016. MEDITS-Handbook. Version n. 8, MEDITS Working Group, 177 pp. http://www.sibm.it/MEDITS\%202011/principaledownload.htm

Alarcón C., Cubillos L., Oyarzún C. 2004. Influencia del tamaño de la hembra en la duración e intensidad de la actividad reproductiva de Merluccius gayi gayi en la zona centro-sur de Chile. Invest. Mar. Valparaiso 32: 59-69. https://doi.org/10.4067/S0717-71782004000200005

Agus B. 2015. Studio sui calamari Loligo vulgaris (Lamarck, 1798) e Loligo forbesii (Streenstrup, 1856) delle acque della Sardegna. PhD thesis, Univ. Cagliari.

Arkhipkin A.I. 1992. Reproductive system structure, development and function in Cephalopods with a new general scale for maturity stages. J. Northwest Atl. Fish. Sci. 12: 63-74.
https://doi.org/10.2960/J.v12.a7

Botsford L.W., Brumbaugh D.R., Grimes C., et al. 2009. Connectivity, sustainability, and yield: bridging the gap between conventional fisheries management and marine protected areas. Rev. Fish Biol. Fish. 19: 69-95.

https://doi.org/10.1007/s11160-008-9092-z

Brown-Peterson N., Wyanski D.M., Saborido-Rey F., et al. 2011. A standardized terminology for describing reproductive development in fishes. Mar. Coast. Fish. 3: 52-70. https://doi.org/10.1080/19425120.2011.555724

Carbonara P., Intini S., Modugno E., et al. 2015. Reproductive biology characteristics of red mullet (Mullus barbatus L., 1758) in Southern Adriatic Sea and management implications. Aquat. Living Resour. 28: 21-31. https://doi.org/10.1051/alr/2015005

Carbonell A., Grau A., Lauronce V., et al. 2006. Ovary development of the red shrimp, Aristeus antennatus (Risso, 1816) from the Northwestern Mediterranean Sea. Crustaceana 79: 727-743. https://doi.org/10.1163/156854006778026807

Cardinale M., Arrhenius F. 2000. The influence of stock structure and environmental conditions on the recruitment process of Baltic cod estimated using a generalized additive model. Can. J. Fish. Aquat. Sci. 57: 2402-2409. https://doi.org/10.1139/cjfas-57-12-2402

Casciaro L., Leonori I., Bitetto I., et al. 2012. GSA 10 - Mare Adriatico meridionale. In Mannini A. and Relini G. (eds). Rapporto annuale sullo stato delle risorse biologiche dei mari circostanti d'Italia: anno 2009. Biol. Mar. Mediterr. 19: 138-161.

Cerri P.S., Sasso-Cerri E. 2003. Staining methods applied to glycol methacrylate embedded tissue sections. Micron 34: 365-372. https://doi.org/10.1016/S0968-4328(03)00098-2

Cuccu D., Mereu M., Porcu C., et al. 2013. Development of sexual organs and fecundity in Octopus vulgaris Cuvier, 1797 from the Sardinian waters (Mediterranean Sea). Medit. Mar. Sci. 14: 270-277. https://doi.org/10.12681/mms.412

D’Onghia G., Capezzuto F., Mytilineou Ch., et al. 2005. Comparison of the population structure and dynamics of Aristeus antennatus (Risso, 1816) between exploited and unexploited areas in the Mediterranean Sea. Fish. Res. 76: 22-38. https://doi.org/10.1016/j.fishres.2005.05.007

Dominguez-Petit R. 2007. Study of reproductive potential of Merluccius merluccius in the Galician Shelf. Ph.D. thesis. Univ. Vigo.

Follesa M.C., Carbonara P. 2019. Atlas of the maturity stages of Mediterranean fishery resources. Studies and Reviews No. 99, FAO, Rome. 268 pp.

Follesa M.C., Cuccu D., Murenu M., et al. 1998. Aspetti riproduttivi negli aristeidi Aristaeomorpha foliacea (Risso, 1827) e Aristeus antennatus (Risso, 1816) della classe di età $0+$ e $1+$. Biol. Mar. Mediterr. 5: 232-238.

Hamlett W.C. 2005. Reproductive biology and phylogeny of Chondrichthyes: sharks, batoids and chimaeras. Sci. Publ. Inc., New Hampshire, USA.

Huret M., Runge J., Chen C., et al. 2007. Dispersal modeling of fish early life stages: sensitivity with application to Atlantic cod in the western Gulf of Maine. Mar. Ecol. Prog. Ser. 347: 261-274. https://doi.org/10.3354/meps06983

ICES 2007. Report of the Workshop on sexual maturity sampling (WKMAT). ICES, CM 2007/ ACOM:03, Copenhagen, Denmark.

ICES 2008. Report of the Workshop on Maturity Ogive Estimation for Stock Assessment (WKMOG), 3-6 June 2008, Lisbon, Portugal. ICES CM2008/ACOM:33: 72 pp.

ICES 2009a. Report of the Planning Group on Commercial Catches, Discards and Biological Sampling (PGCCDBS), 2-6 March 2009, Montpellier, France. ICES CM 2009/ACOM:39: 160 pp.

ICES 2009b. Report of the Workshop on crustaceans (Aristeus antennatus, Aristaeomorpha foliacea, Parapenaeus longirostris, Nephrops norvegicus) maturity stages (WKMSC). ICES CM 2009/ACOM:46, 19-23 October 2009, Messina, Italy. 77 pp.

ICES 2010. Report of the Workshop on Sexual Maturity Staging of Cephalopods. ICES CM 2010/ACOM:49. 8-11 November 2010, Livorno, Italy. 97 pp.

ICES 2013. Report of the Workshop on Sexual Maturity Staging of Elasmobranchs (WKMSEL2) ICES CM 2012/ACOM:59. 1114 December 2012, Lisbon, Portugal. 113 pp.

ICES 2015. Report of the Workshop on Maturity Staging of Mackerel and Horse Mackerel (WKMSMAC2), 28 September-2 October 2015, Lisbon, Portugal. ICES CM 2015/SSGIEOM:17. 
$93 \mathrm{pp}$.

Juanicó M. 1983. Squid maturity scales for population analysis. In: Caddy J.F. (ed.), Advances in assessment of world Cephalopod resources, FAO Fish. Tech. Pap. 231: 341-348.

Junquera S., Saborido-Rey F. 1996. Histological assessment of sexual maturity of the Flemish Cap Cod in 1995. NAFO Sci. Coun. Studies 27: 63-67

Kennedy J., Witthames P.R., Nash R. 2007. The concept of fecundity regulation in place (Pleuronectess platessa) tested on three Irish Sea spawning populations. Can. J. Fish. Aquat. Sci. 64: 587-601. https://doi.org/10.1139/f07-034

Kjesbu O.S. 1994. Time of start of spawning in Atlantic cod (Gadus morhua) females in relation to vitellogenic oocyte diameter, temperature, fish length and condition. J. Fish Biol. 45: 719-735. https://doi.org/10.1006/jfbi.1994.1172

Kjesbu O.S. 2009. Applied fish reproductive biology: contribution of individual reproductive potential to recruitment and fisheries management. In: Jakobsen T., Fogarty M.J., et al. (eds), Fish Reproductive Biology: Implications for Assessment and Mangement, Wiley-Blackwell, Chichester, U.K., pp. 293-332. https://doi.org/10.1002/9781444312133.ch8

Lipinski M. 1979. Universal maturity scale for the commerciallyimportant squids (Cephalopoda: Teuthoidea). The results of maturity classification of the Illex illecebrosus Leseur, (1821) population for years 1973-1977. International Commission for the Northwest Atlantic Fisheries, ICNAF Res. Doc. 79/II/38, 40 pp.

Lowerre-Barbieri S.K. 2009. Reproduction in relation to conservation and exploitation of marine fishes. In: Jameson B.G.M. (ed), Reproductive biology and phylogeny of fishes (agnathans and bony fishes). Science Publishers, Enfield, New Hampshire, pp. 371-394.

Marongiu M.F., Bellodi A., Cau A.1., et al. 2013. Reproductive biology of the blackmouth catshar Galeus melastomus Rafinesque, 1810 in Sardinian seas (central western Mediterranean). Biol. Mar. Mediterr. 20: 190-191.

Marshall C.T., O’Brien L., Tomkiewicz J. 2003. Developing alternative indices of reproductive potential for use in fisheries management: case studies for stocks spanning an information gradient. J. Northwest Atl. Fish. Sci. 33: 161-190. https://doi.org/10.2960/J.v33.a8

Mazzi V. 1977. Tecniche istologiche e istochimiche. Piccin Ed., Padova: $750 \mathrm{pp}$

Morrison C.M. 1990. Histology of the Atlantic cod, Gadus morhua: an atlas. Part three. reproductive tract . Can. Spec. Publ. Fish. Aquat.Sci. 110

Murua H., Saborido-Rey F. 2003. Female reproductive strategies of marine fish species of the North Atlantic. J. Northwest Atl. Fish. Sci. 33: 23-31.
https://doi.org/10.2960/J.v33.a2

Murua H., Kraus G., Saborido-Rey F., et al. 2003. Procedures to estimate fecundity of wild collected marine fish in relation to fish reproductive strategy. J. Northwest Atl. Fish. Sci. 33: 33-54. https://doi.org/10.2960/J.v33.a3

Nuñez J., Duponchelle F. 2009. Towards a universal scale to assess sexual maturation and related life history traits in oviparous teleost fishes. Fish Physil. Biochem. 35: 167-180. https://doi.org/10.1007/s10695-008-9241-2

Pecquerie L., Petitgas P., Kooijman S. 2009. Modeling fish growth and reproduction in the context of the dynamic energy budget theory to predict environmental impact on anchovy spawning duration. J. Sea Res. 62: 93-105. https://doi.org/10.1016/j.seares.2009.06.002

Pesci P. 2006. Ecologia, biologia e struttura di popolazione delle triglie Mullus barbatus Linneo, 1758 e Mullus surmuletus Linneo, 1758 nei mari circostanti la Sardegna. Ph. D. thesis. Univ. Cagliari, Italy.

Porcu C., Marongiu M.F., Follesa M.C., et al. 2014. Reproductive aspects of the velvet belly Etmopterus spinax (Chondrichthyes: Etmopteridae), from the central western Mediterranean Sea. Notes on gametogenesis and oviducal gland microstructure. Medit. Mar. Sci. 15: 313-326. https://doi.org/10.12681/mms.559

Ragonese S., Nardone G., Ottonello D., et al. 2009. Distribution and biology of the blackmouth catshark Galeus melastomus in the Strait of Sicily (central Mediterranean Sea). Medit. Mar. Sci. 1081: 55-72. https://doi.org/10.12681/mms. 122

Rocha F., Guerra Á., González Á.F. 2001. A review of reproductive strategies in Cephalopods. Biol. Rev. 76: 291-304. https://doi.org/10.1017/S1464793101005681

Saborido-Rey F. 2016. Fish Reproduction. In: Cochran J.K., Bokuniewicz J., et al. (eds), Encyclopedia of Ocean Sciences (Third edition), Reference Module in Earth Systems and Environmental Sciences. Academic Press, Oxford, pp. 232-245. https://doi.org/10.1016/B978-0-12-409548-9.09708-6

Tomkiewicz J., Morgan M.J., Burnett J., et al. 2003. Available Information for estimating reproductive potential of Northwest Atlantic groundfish stocks. J. Northwest Atl. Fish. Sci. 33: 1-21. https://doi.org/10.2960/J.v33.a1

Trippel E. 1999. Estimation of stock reproductive potential: history and challenges for Canadian Atlantic gadoid stock assessments. J. Northwest Atl. Fish. Sci. 25: 61-82. https://doi.org/10.2960/J.v25.a6

Tursi A., D'Onghia G., Matarrese A., et al. 1993. Observations on population biology of the blackmouth catshark Galeus melastomus (Chondrichthyes, Scyliorhinidae) in the Ionian Sea. Cybium 17: 187-196. 